\title{
Determination of HBCD, PBDEs and MeO-BDEs in California Sea Lions (Zalophus californianus) Stranded between 1993 and 2003
}

\author{
H. M. Stapleton ${ }^{1}$, N.G. Dodder ${ }^{1}$, J. R. Kucklick ${ }^{2}$, C. M. Reddy ${ }^{3}$, M. M. Schantz ${ }^{1}$, P.R. \\ Becker $^{2}$, F. Gulland ${ }^{4}$, B.J. Porter ${ }^{1}$ and S.A. Wise ${ }^{1}$ \\ 1. Analytical Chemistry Division, National Institute of Standards and Technology, \\ Gaithersburg, MD 20899 \\ 2. Hollings Marine Laboratory, National Institute of Standards and Technology, \\ Charleston, SC 29412 \\ 3. Department of Marine Chemistry and Geochemistry, Woods Hole Oceanographic \\ Institution, Woods Hole, MA 02543 \\ 4. The Marine Mammal Center, Sausalito, CA 94965 \\ Key Words: HBCD, PBDE, flame retardants, California Sea Lions
}

\begin{abstract}
Blubber samples from male California sea lions (Zalphophus californianus) stranded between 1993 and 2003 were analyzed for 27 polybrominated diphenyl ether (PBDE) congeners, three isomers of hexabromocyclododecane (HBCD) and 14 methoxylated polybrominated diphenyl ether (MeO-BDE) congeners. Total PBDEs ranged from $450 \mathrm{ng} / \mathrm{g}$ to $4740 \mathrm{ng} / \mathrm{g}$ wet mass and total $\mathrm{HBCD}$ ranged from $<0.3 \mathrm{ng} / \mathrm{g}$ to $12 \mathrm{ng} / \mathrm{g}$ wet mass. The concentration of HBCD increased from $0.7 \mathrm{ng} / \mathrm{g}$ to $12.0 \mathrm{ng} / \mathrm{g}$ wet mass in sea lion blubber between 1993 and 2003. However, no significant temporal trend was observed for any of the other brominated compounds over this ten year period. Only one of the $14 \mathrm{MeO}-\mathrm{BDE}$ congeners was detected in the blubber samples, 6methoxy- 2,2',4,4'-tetrabromodiphenyl ether (6-MeO-BDE 47), and concentrations ranged from $<0.2 \mathrm{ng} / \mathrm{g}$ to $12 \mathrm{ng} / \mathrm{g}$ wet mass. A bromo-, chloro- heterocyclic compound, 1,1'-dimethyl-tetrabromo-dichloro-2,2'-bipyrrole (DBP- $\left.\mathrm{Br}_{4} \mathrm{Cl}_{2}\right)$, previously reported in marine species along the Pacific coast, was also identified in the sea lion blubber. DBP-
\end{abstract}


$\mathrm{Br}_{4} \mathrm{Cl}_{2}$ ranged from $44 \mathrm{ng} / \mathrm{g}$ wet mass to $660 \mathrm{ng} / \mathrm{g}$ wet mass and was present at concentrations rivaling the dominant PBDE congener, BDE 47 (2, '',4,4'tetrabromodiphenyl ether). Concentrations of $\mathrm{DBP}-\mathrm{Br}_{4} \mathrm{Cl}_{2}$ were positively correlated with 6-MeO-BDE $47(\mathrm{r}=0.7 ; \mathrm{p}<0.05)$. Both of these compounds have been identified in marine algae and sponges, and studies suggest they are both produced from natural sources. This study demonstrates that brominated compounds from both anthropogenic and biogenic sources can accumulate to similar levels in marine mammals. In addition, HBCD concentrations appear to be increasing in California sea lion populations, whereas PBDE concentrations, between 1993 and 2003, were highly variable.

\section{Introduction}

Many recent studies have shown that brominated compounds can bioaccumulate in freshwater and marine systems ${ }^{1-6}$. Most of the brominated compounds measured are anthropogenic and synthesized for the purpose of flame-retarding consumer products such as furniture, carpets, TVs and computer components ${ }^{7,8}$. Brominated flame retardants (BFRs) include compounds such as polybrominated diphenyl ethers (PBDEs), hexabromocyclododecane (HBCD) and tetrabromobisphenol-A (TBBPA). However, some brominated compounds measured in aquatic food webs are believed to be naturally produced by algae and/or sponges ${ }^{9-13}$. Tittlemier et al. ${ }^{9}$ identified a mixed chloro-, bromo-heterocyclic compound in Pacific sea bird eggs that was recently shown to be naturally produced using radiocarbon dating ${ }^{12}$. Methoxylated polybrominated diphenyl ethers (MeO-BDEs), have been identified in Baltic Sea organisms ${ }^{14,15}$ and dolphins from Australia ${ }^{10,11}$ and the Mediterranean Seas ${ }^{16}$ in concentrations as high as $3.8 \mu \mathrm{g} / \mathrm{g}$ 
blubber. These MeO-BDEs have also been isolated from marine sponges (Dysidea sp.) ${ }^{10}$ and suggest that naturally produced organohalogen compounds can bioaccumulate in a manner similar to anthropogenic organohalogen compounds like polychlorinated biphenyls (PCBs) and PBDEs. However, given the similarity in structures between MeO-BDEs and PBDEs, the possibility of metabolic formation of MeO-BDEs from PBDEs, cannot be ruled out.

Temporal studies have shown that the levels of PBDEs are increasing in environmental matrices ${ }^{17-20}$, presumably due to increased use of these flame retardant chemicals in consumer products. In 2001, the global market demand for PBDEs was approximately 67,400 metric tons ${ }^{21}$. However, the European Union has phased out the use of two of the three commercial PBDE mixtures, pentaBDE and octaBDE. DecaBDE is the third mixture and is comprised almost entirely of decabromodiphenyl ether, BDE 209. The states of California and Maine, in the United States, have enacted legislation to prevent the use of pentaBDE and octaBDE in products sold within these states. ${ }^{21}$ Additionally, the sole manufacturer of pentaBDE and octaBDE in the United States, Great Lakes Chemical Co., has voluntarily agreed to stop producing these mixtures. ${ }^{22}$ Therefore, the use of these PBDE mixtures in consumer products is expected to decrease in the future and there is evidence that this is occurring in some locations ${ }^{23}$. HBCD, in contrast, had a global market demand of 16,700 metric tons, as reported in $2001^{21}$, and is currently unregulated. Very few studies have reported HBCD measurements in environmental samples and little information is available on its fate and persistence in the environment. $\mathrm{HBCD}$ has been measured in food webs in Lake Ontario ${ }^{6}$ and in the North Sea ${ }^{4}$, with biomagnification of HBCD demonstrated at both sites. A study in Sweden 
found that $\mathrm{HBCD}$ was increasing in guillemot eggs from the Baltic Sea at a rate of about $3 \%$ per year ${ }^{24,25}$.

This study was undertaken to examine the concentration of naturally produced brominated compounds (i.e., MeO-BDEs) and two anthropogenic brominated flame retardants, PBDEs and HBCD, in California sea lions (Zalophus californianus) stranded along the California coast over the past ten years. California sea lions are a marine mammal that inhabits coastal areas of the eastern North Pacific Ocean, and, because of its close association with urban near-shore areas, has been used in previous studies as a sentinel of environmental contamination by persistent organochlorine pollutants ${ }^{26-28}$. The objective of this study was to determine if the concentrations of BFRs are changing in stranded sea lions over the past ten years which would be reflective of the increased production and use of these compounds over the past twenty years. A second objective was to measure $\mathrm{MeO}-\mathrm{BDEs}$ and determine if their concentrations were correlated to PBDE concentrations, which may support a metabolic source.

\section{Materials and Methods}

\section{Samples}

Blubber samples from 25 male California sea lions were selected for analysis from the National Marine Mammal Tissue Bank (NMMTB) at the National Institute of Standards and Technology's (NIST's) environmental specimen bank facilities in Gaithersburg, MD and Charleston, SC. NIST maintains the NMMTB to provide archived samples for retrospective analysis and is run in conjunction with the National Marine Fisheries Service’s (NMFS's) Marine Mammal Health and Stranding Response Program. All 
California sea lions samples banked in this program were collected by the Marine Mammal Center in Sausalito, California. Tissues from California sea lions that had recently stranded, or had been euthanized by the Marine Mammal Center, were sampled and cryogenically preserved according to established procedures ${ }^{29,30}$. Tissue samples were only taken from stranded animals that were considered "freshly dead", which typically meant that the animal had died within the past 24 hours. Morphometric information and histological analyses were performed on all animals for which samples were taken and included in the NMMTB. Teeth were also removed to determine age by counting growth layer groups ${ }^{31}$. One specimen has not been aged (B260 in Table 1) but it has been estimated at 4 to 8 years based on the size and development of the sagittal crest. All blubber samples were cryogenically homogenized according to NIST's standard procedure ${ }^{29}$.

In addition to these 25 banked samples, an additional sample (labeled sample 2000D in Table 1) was analyzed with this sample set for a total of 26 samples. This sample was recently used in a NIST inter-laboratory comparison exercise for organochlorine compounds and contains blubber taken from two California sea lions of unknown sex that stranded in 2000. Males were selected for this study to avoid effects of lactation and reproduction (observed in females) on concentrations of contaminants that may interfere with the determination of temporal trends.

\section{Materials}

Chemical standards used in this study were purchased from either Cambridge Isotope Laboratories (Andover, MA, USA), Accustandard (New Haven, CT, USA) or Wellington Laboratories (Guelph, ON, Canada), with the exception of the MeO-BDEs 
and $\mathrm{DBP}-\mathrm{Br}_{4} \mathrm{Cl}_{2}$. The MeO-BDE standards were a gift from Dr. Rob Letcher (University of Windsor, Windsor, ON, Canada) and Dr. Göran Marsh (Stockholm University, Sweden) and were synthesized by Dr. Marsh ${ }^{32}$. DBP- $\mathrm{Br}_{4} \mathrm{Cl}_{2}$ was a gift from Dr. Sheryl Tittlemier (Heath Canada, Ottawa, Ontario) ${ }^{12,33}$. The solution of MeO-BDEs contained 14 congeners: 6'-MeO-BDE 17, 2'-MeO-BDE 28, 6'-MeO-BDE 49, 2-MeO-BDE 68, 6MeO-BDE 47, 3-MeO-BDE 47, 5-MeO-BDE 47, 4'-MeO-BDE 49, 4-MeO-BDE 42, 6MeO-BDE 90, 6-MeO-BDE 99, 2-MeO-BDE 123, 6-MeO-BDE 85, and 6-MeO-BDE 137. A PBDE solution containing 27 PBDE congeners (Suppl. Table 1) was prepared from solid material purchased from Accustandard (New Haven, CT, USA). The internal standards used for the analysis of tri- through octaBDEs, MeO-BDEs and $\mathrm{DBP}-\mathrm{Br}_{4} \mathrm{Cl}_{2}$ included ${ }^{13} \mathrm{C}$ labeled 2,2',3,4,5-pentachlorodiphenyl ether (CDE 86); and ${ }^{13} \mathrm{C}$ labeled 4,4'-dibromodiphenyl ether (BDE 15), purchased from Cambridge Isotope Laboratories (Andover, MA, USA). NonaBDEs and decabromodiphenyl ether (BDE 209) were quantified using ${ }^{13} \mathrm{C}$ labeled decabromodiphenyl ether, also purchased from Cambridge Isotope Laboratories. ${ }^{13} \mathrm{C}$ labeled $\gamma$-HBCD was used as an internal standard for the quantification of HBCD isomers and was purchased from Wellington Laboratories (Guelph, ON, Canada). All solvents used were HPLC grade.

\section{Extraction and Cleanup}

A pressurized fluid extractor (PFE) was used to extract the blubber samples with dichloromethane. Approximately $1.5 \mathrm{~g}$ of sea lion blubber was mixed with pre-cleaned sodium sulfate and ground to a fine powder. Sodium sulfate was Soxhlet extracted with dichloromethane for 24 hours and vacuum dried prior to use. This mixture was poured 
into 22mL PFE cells and spiked with the internal standards described above. All samples, blanks and calibration solutions were extracted using the following program parameters: temperature $100^{\circ} \mathrm{C}$, heat time $5 \mathrm{~min}$, static time $5 \mathrm{~min}$, and pressure $13.8 \mathrm{MPa}$ (2000 psig), for three cycles. Extracts were reduced in volume using nitrogen delivered by an automated evaporation system. The lipid content of the extracts was measured gravimetrically and then removed from the remaining extract using size exclusion chromatography (SEC) with a divinylbenzene-polystyrene column (10 $\mu \mathrm{m}$ particle size, $100 \AA$ pore size, $2.5 \mathrm{~cm}$ i.d. x $60 \mathrm{~cm}$, PL-Gel, Polymer Labs, Inc., Amherst, MA, USA). Samples were eluted through the column using a mobile phase of $100 \%$ dichloromethane (DCM) at a flow rate of $10.0 \mathrm{~mL} / \mathrm{min}$. The collected eluent was reduced in volume and transferred into hexane. As a final clean up step the extracts were eluted through silica solid-phase extraction cartridges (Waters, Milford, MA, USA) with $20 \mathrm{~mL}$ of $20 \%(\mathrm{v} / \mathrm{v}) \mathrm{DCM}$ in hexane, and again reduced in volume using nitrogen gas to $0.5 \mathrm{~mL}$. Extracts in hexane were first analyzed for PBDEs using gas chromatography mass spectrometry. After PBDE analysis the extracts were reduced to dryness using nitrogen gas and then re-solubilized in $100 \mu \mathrm{L}$ of methanol for LC/MS-MS measurement of HBCD.

\section{Instrumental Analysis}

Extracts were analyzed for PBDEs, MeO-BDEs and $\mathrm{DBP}-\mathrm{Br}_{4} \mathrm{Cl}_{2}$ using gas chromatography (GC; Agilent GC 6890, Palo Alto, CA, USA) with a mass spectrometer (Agilent MS 5973, Palo Alto, CA, USA) operated in both electron capture negative ionization (GC/ECNI-MS) and electron impact ionization (GC/EI-MS). A $0.25 \mathrm{~mm} \times 15$ m fused silica capillary column coated with a $5 \%$ (mole fraction) phenyl 
methylpolysiloxane column (DB-5MS, 0.25 Фm film thickness; J \& W Scientific) was used for the separation of the analytes in the GC. On-column injection was employed in the $\mathrm{GC}$ and the injection port was set to track the oven temperature. The oven temperature was initially held at $80 \mathrm{EC}$ for $2 \mathrm{~min}$ and then ramped to $140 \mathrm{EC}$ at a rate of $12 \mathrm{EC} / \mathrm{min}$, followed by a temperature ramp of $5 \mathrm{EC} / \mathrm{min}$ to a final temperature of 280 EC, which was held for an additional $20 \mathrm{~min}$. The transfer line was maintained at 280 EC. The ion source and quadrupole were maintained at $200{ }^{\circ} \mathrm{C}$ and $100{ }^{\circ} \mathrm{C}$, respectively. PBDEs, MeO-BDEs and DBP- $\mathrm{Br}_{4} \mathrm{Cl}_{2}$ were measured using $\mathrm{GC} / \mathrm{ECNI}-\mathrm{MS}$ by monitoring $\mathrm{m} / \mathrm{z} 79$ and 81 (bromine ions) with the exception of BDE 209, which was monitored using ions $487\left[\mathrm{C}_{6} \mathrm{Br}_{5} \mathrm{O}-\right]$ and $409\left[\mathrm{C}_{6} \mathrm{Br}_{4} \mathrm{O}-\right]^{34}$. The chlorinated internal standard (CDE 86) was monitored using a molecular fragment $\left[{ }^{13} \mathrm{C}_{12} \mathrm{Cl}_{4} \mathrm{O}\right]$ - at $\mathrm{m} / \mathrm{z} 318$ and 316 . GC/EI-MS was used to confirm and quantify all analytes with the exception of HBCD. PBDEs were quantified using $\mathrm{GC} / \mathrm{EI}-\mathrm{MS}$ by monitoring the $\mathrm{M}+$ and $[\mathrm{M}-2 \mathrm{Br}]^{+}$ions for each homologue group. 6-MeO-BDE 47 was quantified in GC/EI-MS mode by monitoring the $[\mathrm{M}]+$ ion at $\mathrm{m} / \mathrm{z} 516$ and 514. $\mathrm{DBP}-\mathrm{Br}_{4} \mathrm{Cl}_{2}$ was quantified by monitoring the $[\mathrm{M}]+$ ions at $\mathrm{m} / \mathrm{z} 544$ and 546. A five point calibration curve was used to quantify PBDEs and ranged in concentration from $0.06 \mathrm{ng} / \mathrm{mL}$ to $1000 \mathrm{ng} / \mathrm{mL}$. A one point calibration curve was used for the quantification of MeO-BDEs and $\mathrm{DBP}-\mathrm{Br}_{4} \mathrm{Cl}_{2}$ due to the limited availability of the standards.

$\mathrm{HBCD}$ consists of three stereo isomers known as $\alpha-\mathrm{HBCD}, \beta-\mathrm{HBCD}$ and $\gamma-$ HBCD. Typical GC/MS analyses are unable to resolve these three isomers; however, liquid chromatography combined with mass spectrometry (LC/MS-MS) has been shown to provide the required selectivity ${ }^{35}$. An API 4000 triple quadrupole mass spectrometer 
(Applied Biosystems/Sciex, Concord, ON, Canada) was operated in negative mode electrospray ionization and coupled to an 1100 series HPLC system (Agilent, Palo Alto, CA, USA). The method used here for the quantification of $\mathrm{HBCD}$ is very similar to the method used by Budakowski and Tomy ${ }^{35}$, with the exception of the LC column used. In this study a $\mathrm{C}_{30}$ YMC Carotenoid S-5, 4.6 x $250 \mathrm{~mm}$, HPLC column (Waters Co., Milford, MA, USA) was used for the separation of the three HBCD isomers and provided baseline separation of the alpha, gamma and beta isomers (elution order, respectively). The flow rate through the column was $0.5 \mathrm{~mL} / \mathrm{min}$ using a gradient elution initially set at water/methanol (20:80 by volume), and then ramped to $100 \%$ methanol over $35 \mathrm{~min}$. The injection volume was $5 \mu \mathrm{L}$. The multiple reaction monitoring (MRM) transition was $[\mathrm{M}-\mathrm{H}]^{-} \rightarrow \mathrm{Br}^{-}$at $m / z 640.8 \rightarrow 78.8$ for the three $\mathrm{HBCD}$ isomers and the MRM transition

for the ${ }^{13} \mathrm{C}$ labeled $\gamma$-HBCD internal standard was $652.8 \rightarrow 78.8$. A four point calibration curve was used for the quantification of $\mathrm{HBCD}$ and ranged from $10 \mathrm{ng} / \mathrm{mL}$ to $100 \mathrm{ng} / \mathrm{mL}$.

$Q A / Q C$

The PBDE limits of quantification using GC/ECNI-MS was determined by using a signal to noise $(\mathrm{S} / \mathrm{N})$ of 50 , and ranged from $1 \mathrm{pg}$ to $50 \mathrm{pg}$ on column for the various congeners. Using an extraction mass of $1.5 \mathrm{~g}$, an injection volume of $2 \mu \mathrm{L}$ and correcting for blank contamination, the method detection limits (MDL) ranged from $0.5 \mathrm{ng} / \mathrm{g}$ to 1.0 ng/g wet mass. The HBCD limits of quantification using LC/MS-MS was determined by using a signal to noise ( $\mathrm{S} / \mathrm{N})$ of 100 , which ranged from $5 \mathrm{pg}$ to $25 \mathrm{pg}$ on column. MDLs for $\mathrm{HBCD}$ were $0.3 \mathrm{ng} / \mathrm{g}$ wet mass for each $\mathrm{HBCD}$ isomer. PBDEs, MeO-BDEs and DBP- $\mathrm{Br}_{4} \mathrm{Cl}_{2}$ were all quantified using both GC/ECNI-MS and GC/EI-MS. Results 
agreed well with each other for both GC/ECNI-MS and GC/EI-MS and were within 20\% of each other. The results from the GC/ECNI-MS quantification are reported in Table 1 because the GC/ECNI-MS had greater sensitivity.

BDE 47 (2,2',4,4'-tetrabromodiphenyl ether), BDE 99 (2,2',4,4',5pentabromodiphenyl ether) and BDE 209 were detected in laboratory blanks and ranged from $0.3 \mathrm{ng}$ to $0.7 \mathrm{ng},<0.05 \mathrm{ng}$ to $0.3 \mathrm{ng}$, and from 0.1 to $1.0 \mathrm{ng}$, respectively; however, levels were low enough to exclude the need for blank correction. Levels of MeO-BDEs, DBP- $\mathrm{Br}_{4} \mathrm{Cl}_{2}$ and $\mathrm{HBCD}$ were all below MDLs $(0.2 \mathrm{ng} / \mathrm{g}, 0.2 \mathrm{ng} / \mathrm{g}$ and $0.3 \mathrm{ng} / \mathrm{g}$ wet mass for $\mathrm{MeO}-\mathrm{BDEs}, \mathrm{DBP}-\mathrm{Br}_{4} \mathrm{Cl}_{2}$ and $\mathrm{HBCD}$, respectively) in laboratory blanks. Replicate extractions were performed on two of the blubber samples and values for the replicates were within $20 \%$ of each other for $\Sigma$ PBDEs, within $15 \%$ of each other for MeO-BDEs and DBP- $\mathrm{Br}_{4} \mathrm{Cl}_{2}$ and within $5 \%$ of each other for $\Sigma \mathrm{HBCD}$ (which is primarily $\alpha-\mathrm{HBCD}$ ). Marine mammal blubber standard reference material (SRM 1945), supplied by NIST, was used as a quality control material to ensure accuracy in measuring PBDE concentrations. PBDE concentrations measured in SRM 1945 ranged from 76 to $100 \%$ of the reference values reported for PBDEs in this SRM ${ }^{36,37}$. HBCD method recovery was assessed by spiking three sodium sulfate blanks with approximately $25 \mathrm{ng}$ of $\alpha$-HBCD and carrying these spikes through the entire extraction method. Recoveries of $\alpha-\mathrm{HBCD}$ ranged from $86 \%$ to $93 \%$. All reported concentrations are corrected for recovery.

\section{Statistical Analyses}

Variables such as lipid content, blubber thickness, age, mass, length and year of stranding can all have an effect on the contaminant loadings in the sea lion blubber. To 
try and examine the effect of these variables on contaminant levels within the sea lion tissues, individual correlation analyses were run among all variables and contaminant levels and are presented in the correlation matrix (Table 2). A significant correlation ( $\mathrm{R}$ $=0.80, \mathrm{p}<0.01)$ was observed for the effect of date of stranding on HBCD levels. To test for co-variance, multiple linear regression was performed on the log transformed $\mathrm{HBCD}$ data considering age, lipid, mass and length as independent variables. Statistical significance was set at $\mathrm{p} \leq 0.01$. Samples with contaminant concentrations below the MDL were assigned a value equivalent to the MDL for the statistical analyses.

\section{Results and Discussion}

\section{Lipid Measurements}

Lipid content was highly variable among blubber samples, ranging from $6 \%$ to $79 \%$, and was not correlated with the concentrations of any of the brominated compounds. A low lipid measurement $(<50 \%)$ in blubber may indicate that some of the animals were nutritionally stressed prior to stranding which would deplete their lipid stores. Blubber thickness was measured in the sea lion tissues (Table 1) and was positively correlated to \% lipid (Table 2), reinforcing this idea. This variance has been

observed previously in stranded California sea lions ${ }^{38}$. Due to this variability in the blubber lipid content, and the lack of a correlation between lipid and contaminant levels, the concentrations are reported in all tables and figures in terms of $\mathrm{ng} / \mathrm{g}$ wet mass. 
$H B C D$

HBCD was detected in $81 \%$ of the samples analyzed and ranged in concentration from $<0.3 \mathrm{ng} / \mathrm{g}$ to $12 \mathrm{ng} / \mathrm{g}$ wet mass (Table 1 ), and from $<0.4 \mathrm{ng} / \mathrm{g}$ to $96 \mathrm{ng} / \mathrm{g}$ lipid. $\alpha$ $\mathrm{HBCD}$ was the dominant isomer detected in all samples and ranged from $62 \%$ to $100 \%$ of the total HBCD measured in all sea lion samples. Tomy et al. ${ }^{6}$ observed a higher rate of biomagnification for the $\alpha$-HBCD isomer compared to the $\gamma-\mathrm{HBCD}$ isomer in a Lake Ontario food web. Zegers et al. ${ }^{39}$ reported a predominance of $\alpha-\mathrm{HBCD}$ in harbor porpoises (Phocoena phocoena) and common dolphins (Delphinus delphis) from the European Coast. Results from in vitro studies conducted using harbor seal liver microsomes have also suggested that $\alpha$-HBCD is more resistant to P450 mediated biotransformation than the $\beta$ - and $\gamma$-HBCD stereoisomers ${ }^{39}$, and that $\beta$ - and $\gamma$-HBCD may be absent in some species due to efficient metabolism.

The HBCD levels measured in sea lions in this study are lower than levels measured in fish, porpoises and seals from the North $\mathrm{Sea}^{4}$; fish from the Cinca River in Spain ${ }^{40}$ and peregrine falcon eggs in Sweden ${ }^{41}$. This trend may reflect the greater demand for $\mathrm{HBCD}$ in Europe relative to North and South America, which was reported at 9,500 metric tons and 2,800 metric tons, respectively, in $2001^{21}$. This trend is also reflected in the study by Tomy et al. ${ }^{6}$ which measured HBCD in a Lake Ontario food web and found that the HBCD levels in Lake Ontario fish are lower than levels measured in fish from European waters. No significant trends were observed between $\Sigma H B C D$ and mass, length, lipid or age of the sea lions (Table 2). The only significant trend was between $\Sigma H B C D$ and date of stranding, which will be discussed below. 
PBDES

These sea lion blubber samples were analyzed for 27 individual PBDE congeners ranging from tribromodiphenyl ethers through decabromodiphenyl ether (BDE 209). BDE 209 was not present $(<1.0 \mathrm{ng} / \mathrm{g}$ wet weight $)$ in any of the samples examined. Tribromo- through heptabromodiphenyl ethers were detected in all sea lion samples analyzed and ranged in total concentration from $450 \mathrm{ng} / \mathrm{g}$ to $4740 \mathrm{ng} / \mathrm{g}$ wet mass (Table 1) or from $570 \mathrm{ng} / \mathrm{g}$ to $24,240 \mathrm{ng} / \mathrm{g}$ lipid. The geometric mean was $1470 \mathrm{ng} / \mathrm{g}$ wet mass, or $3900 \mathrm{ng} / \mathrm{g}$ lipid. These $\Sigma$ PBDE levels are some of the highest levels ever reported for marine mammals and are higher than levels measured in killer whales (Orcinus orca) from the Northeastern Pacific ${ }^{42}$, northern fur seals (Callorhinus ursinus) from the Pacific coast of Japan ${ }^{43}$, grey seals (Halichoerus grypus) from the North Sea ${ }^{44}$ and polar bear (Ursus maritimus) and beluga whales (Delphinapterus leucas) from the Arctic ${ }^{3}$. However, they are comparable to levels measured in male Atlantic white-sided dolphins (Lagenorhynchus acutus) ${ }^{45}$, harbor porpoises from England and Wales ${ }^{46}$ and San Francisco harbor seals (Phoca vitulina) ${ }^{19}$. No correlation was observed between $\Sigma$ PBDEs and HBCD in these sea lion samples.

BDE 47 (2,2',4,4'-tetrabromodiphenyl ether) was the dominant congener in all sea lions measured and represented $55 \% \pm 8 \%$ of the total PBDE burden (Figure 1). BDE 100 (2,2', 4,4',6-pentabromodiphenyl ether) and BDE 99 (2,2',4,4',5pentabromodiphenyl ether) contributed $20 \% \pm 7 \%$ and $12 \% \pm 3 \%$, respectively. This congener pattern is very similar to BDE congener patterns observed in other marine mammals $3,19,42,45$. Generally, BDE 99 is found in the highest percentage in the pentaBDE commercial mixtures, followed by BDE 47 and BDE $100^{47}$. The fact that 
BDE 100 is generally higher in concentration than BDE 99 in these sea lion samples may indicate that sea lions metabolize BDE 99 to some degree. In vivo laboratory exposures have shown that the common carp debrominates BDE 99 to form $\operatorname{BDE} 47^{48}$. It is possible that sea lions may possess a similar metabolic capacity to debrominate BDE 99 which results in an increased accumulation of BDE 47 within their tissues and a relative depletion of BDE 99. In contrast, we cannot rule out the possibility that this congener pattern in the sea lion tissue reflects the pattern in their source of exposure, primarily their diet.

\section{Methoxylated PBDEs}

California sea lion blubber samples were analyzed for 14 individual methoxylated polybrominated diphenyl ethers (MeO-BDEs). Only one $\mathrm{MeO}-\mathrm{BDE}$ was positively identified, 6-MeO-BDE 47 (Figure 2). Concentrations ranged from $<0.2 \mathrm{ng} / \mathrm{g}$ to $12 \mathrm{ng} / \mathrm{g}$ wet mass and are comparable to levels of MeO-BDEs measured in grey and ringed seals (Phoca hispida) from the Baltic Sea ${ }^{14}$ and dolphins from the Mediterranean Sea ${ }^{16}$. If MeO-BDEs were formed from the metabolism of PBDEs, it would most likely occur via the cytochrome P450 system. Cytochrome P450s have been shown to metabolize PCBs and PBDEs to hydroxylated analogues ${ }^{49}$. If PBDEs were metabolized to MeO-BDEs, the first step would be the oxidation of a PBDE congener by a CYP enzyme followed by enzyme-mediated methylation. Oxidation of PCBs and PBDEs via CYP enzymes has typically been observed in the meta- and para-positions relative to the diphenyl ether bond $^{49-51}$. 6-MeO-BDE 47, which was identified in the sea lion blubber, has a methoxy group present in the ortho- position, which lends support to a biogenic origin. In 
addition, Malmvärn et al. ${ }^{52}$ recently identified 6-MeO-BDE 47 in the red algae Ceramium sp. and blue mussels in the Baltic Sea and concluded that this compound was produced either from the red algae itself or associated microflora and/or microfauna. Teuten et al. ${ }^{13}$ also recently identified 6-MeO-BDE 47 and 2-MeO-BDE-68 in True's beaked whales (Mesoplodon mirus) and determined it was of a non-anthropogenic origin based on its radiocarbon content.

There was no correlation between levels of 6-MeO-BDE 47 and BDE 47 $(\mathrm{p}<0.01)$, nor were there any correlations with other PBDE congeners. Levels of 6-MeOBDE 47 were, however, positively correlated with another brominated compound observed in all GC/ECNI-MS chromatograms (Figure 2), which was determined to be DBP- $\mathrm{Br}_{4} \mathrm{Cl}_{2}$. This compound was identified by acquiring full-scan EI and ECNI mass spectra and comparing it to the full-scan and GC retention times of a synthetic standard of DBP- $\mathrm{Br}_{4} \mathrm{Cl}_{2}$. Figure 3 presents the full scan EI spectra obtained for $\mathrm{DBP}-\mathrm{Br}_{4} \mathrm{Cl}_{2}$ in the sea lion extract, which compares very well to the spectra obtained by Tittlemier et al. ${ }^{9}$. $\mathrm{DBP}-\mathrm{Br}_{4} \mathrm{Cl}_{2}$ is a mixed bromo-, chloro-heterocyclic compound which has only been identified in marine species. It has been found in Pacific seabird eggs at levels 1.5 to 2.5 times higher than levels in Atlantic seabird eggs ${ }^{9}$, and here we have identified DBP$\mathrm{Br}_{4} \mathrm{Cl}_{2}$ in another Pacific marine organism, the California sea lion. Concentrations of DBP- $\mathrm{Br}_{4} \mathrm{Cl}_{2}$ ranged from $44 \mathrm{ng} / \mathrm{g}$ to $660 \mathrm{ng} / \mathrm{g}$ wet mass and were comparable to the levels of BDE 47. Reddy et al. ${ }^{12}$ recently isolated $\mathrm{DBP}-\mathrm{Br}_{4} \mathrm{Cl}_{2}$ from marine organisms to perform a radiocarbon analysis to determine the age of the carbon and confirmed that DBP- $\mathrm{Br}_{4} \mathrm{Cl}_{2}$ is of a biogenic origin. DBP- $\mathrm{Br}_{4} \mathrm{Cl}_{2}$ and 6-MeO-BDE 47 concentrations in California sea lions were significantly correlated (Figure $4 ; \mathrm{r}=0.7 ; \mathrm{p}<0.05$ ). The lack of 
a correlation between 6-MeO-BDE 47 and $\mathrm{BDE} 47$, and the positive correlation between DBP- $\mathrm{Br}_{4} \mathrm{Cl}_{2}$ and 6-MeO-BDE 47, suggests that the latter compounds may both accumulate from natural sources. No information is available to determine if there are any potential toxicity concerns associated with exposure to these biogenic brominated compounds.

\section{Contaminant Trends}

The California sea lions in this study were stranded between 1993 and 2003 (Table 1), which provided an opportunity to examine the changes in the accumulation of brominated compounds in the blubber of sea lions during this time. The number of sea lion samples that were collected and banked were not uniform every year between 1993 and 2003 and therefore there are limitations on the temporal trend analyses conducted here. However, we can make some general observations on contaminant trends based on the available samples. No significant temporal trend was observed in the concentrations of 6-MeO-BDE 47, $\mathrm{DBP}-\mathrm{Br}_{4} \mathrm{Cl}_{2}$ or $\Sigma \mathrm{PBDEs}$ (Figure 5). Additionally, no temporal trend was evident in the concentrations of individual PBDE congeners. Previous studies have shown that $\Sigma$ PBDEs in San Francisco harbor seal blubber were increasing over the period 1989 to $1998{ }^{19}$, in Arctic ringed seals from 1981 to $2000^{17}$, in Great Lakes herring gull eggs (Larus argentatus) from 1981 to $2000{ }^{18}$ and in northern fur seals collected in Japan between 1972 to $1998^{43}$. The majority of these studies that have observed a temporal increase in $\Sigma$ PBDEs have examined samples collected, or archived, starting in the 1970s to 1980 s and continuing up through the year 2000. Kajiwara et al. ${ }^{43}$ observed a 150 fold increase in $\Sigma$ PBDEs in fur seals from 1972 to the 1994, but then an apparent decrease in 
concentration from 1994 to 1998 . Sellström et al. ${ }^{24}$ observed an increase in $\Sigma$ PBDEs in guillemot eggs from the Baltic Sea from 1970 to the mid 1980s, followed by a significant decrease up to 2001. Additionally, studies from Sweden have shown that PBDEs in human breast milk increased from 1970 to 1997, but then decreased from 1997 to 2000 53. Based on these latter studies, it may be possible that PBDEs have reached a peak concentration in sea lion blubber. A recent study on Atlantic dolphins sampled between 1993 and 2000 also found no temporal trend for PBDEs $^{45}$. Differences in PBDEs levels among the sea lions may also be a consequence of the sea lions feeding in different locations up and down the California coast that may have different PBDE loadings. In contrast, $\Sigma \mathrm{HBCD}$ increased $\left(\mathrm{r}^{2}=0.63 ; \mathrm{p}<0.01\right)$ in California sea lion blubber between 1993 and 2003. Multiple linear regression was performed on the data set which included $\Sigma \mathrm{HBCD}, \%$ lipid, age, mass and length. The only significant $(\mathrm{p}<0.01)$ independent variable was the date of stranding. Concentrations of HBCD appear to be increasing almost exponentially (Figure 5); however, the number of samples in this study may be too limited to make an accurate estimation of the $\mathrm{HBCD}$ accumulation rate in sea lion blubber. If we assume this increase is exponential, then the doubling time of HBCD in sea lion blubber between 1993 and 2003 is approximately 2 years. Doubling times calculated for PBDEs between 1970 to 2000 in various media have been reported at about 5 years for human blood, milk and tissues ${ }^{54}, 3$ years for Great Lakes herring gull eggs ${ }^{18}$ and from 4 to 9 years for Arctic ringed seals ${ }^{17}$. Sellström et al. ${ }^{24}$ reported an increase in HBCD in guillemot eggs from the Baltic Sea from the early 1980s, but concentrations have remained relatively stable from 1991 to 2001 . 
It is unclear at this time why HBCD levels are increasing in sea lion blubber while PBDE levels are variable. According to the Bromine Science and Environmental Forum (www.bsef.com), the world market demand for HBCD increased from 15,900 Metric Tons to 16,700 Metric Tons between 1999 and 2001, while the demand for pentaBDE decreased from 8500 Metric Tons to 7500 Metric Tons. This trend in the sea lion tissues may be related to the relative production and use of HBCD compared to pentaBDE. To the authors' knowledge, this is the first report of increasing HBCD concentrations in a marine mammal population.

In field studies, HBCD was observed to have a biota/sediment accumulation factor of about $15^{55}$, suggesting it is fairly bioaccumulative. Only a few studies have examined the potential toxicity and metabolism of $\mathrm{HBCD}^{56,57}$. In general, $\mathrm{HBCD}$ appears not to be acutely toxic to rats, mice or fish, but chronic exposure can lead to increased liver weights, thyroid hyperplasia and increase intragenic recombination in in vitro assays ${ }^{56-58}$. It also has potential neurotoxicological effects by inhibiting the uptake of the neurotransmitters dopamine, glutamate, and $\gamma$-amino-n-butyric acid in rat brain tissue ${ }^{59}$. Considering the rapid rate of increase in HBCD concentrations in sea lions, and the potential toxicity concerns, more studies on the loadings and concentrations of HBCD in other environmental media may be warranted.

This study has shown that biogenic brominated compounds can be found at levels comparable to anthropogenic persistent organic pollutants. There was no correlation between PBDEs and MeO-BDEs, which suggests that MeO-BDEs in California sea lion is not primarily due to metabolism of PBDEs. This work demonstrates that HBCD has increased in concentration in sea lion blubber whereas $\Sigma$ PBDE concentrations appear to 
be stable and have not changed significantly over the past ten years. Future monitoring should be conducted to determine if PBDEs will decrease in the future now that these compounds will no longer be used as flame retardants.

Acknowledgements: The authors acknowledge Rob Letcher of the University of Windsor and Göran Marsh of Stockholm University for the generous gift of the MeOBDE standards and we would like to thank Sheryl Tittlemier for supplying the standard for DBP- $\mathrm{Br}_{4} \mathrm{Cl}_{2}$ to C. Reddy; Rebecca Pugh and Michael Ellisor for their assistance in providing blubber samples, and Dave Deuwer for his help in the statistical analysis, and the support and advice of Teri Rowles, Program Manager of the Marine Mammal Health and Stranding Response Program, NMFS Office of Protected Resources

Disclaimer: Certain commercial equipment, instruments, or materials are identified in this paper to specify adequately the experimental procedure. Such identification does not imply recommendation or endorsement by the National Institute of Standards and Technology, nor does it imply that the materials or equipment identified are necessarily the best available for the purpose. 


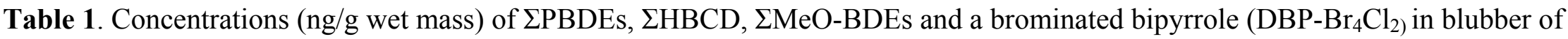
California sea lions with information on age, length, mass, lipid content, blubber thickness and date of stranding.

\begin{tabular}{|c|c|c|c|c|c|c|c|c|c|c|}
\hline Sample & $\%$ lipid & Mass (kg) & Length $(\mathrm{cm})$ & Age (years) & Stranded & $\begin{array}{l}\text { Blubber } \\
\text { Thickness }(\mathrm{cm})\end{array}$ & $\underline{\Sigma P B D E}$ & $\underline{\underline{H B C D}}$ & $\underline{\Sigma M e O-B D E}$ & DBP-Br4Cl \\
\hline B052 & 13.3 & 69 & 175 & 8 & $10 / 27 / 93$ & 0.7 & 2370 & 0.71 & 4.56 & 644 \\
\hline B059 & 79.2 & 121.5 & 242.5 & 12 & 05/05/96 & 5.5 & 451 & $<0.3$ & 3.91 & 196 \\
\hline B078 & 20.2 & 199.6 & 126 & 11 & $08 / 20 / 96$ & 12 & 936 & 1.51 & 11.62 & 579 \\
\hline B081 & 60.5 & 104 & 188 & 4.5 & $10 / 29 / 96$ & 2.5 & 3245 & 1.33 & $<0.2$ & 193 \\
\hline B084 & 8.2 & 139 & 210 & 11 & $10 / 26 / 96$ & 0.9 & 1537 & 1.12 & 2.67 & 219 \\
\hline B088 & 55.4 & 78 & 164 & 7 & $11 / 06 / 96$ & 1.8 & 1016 & $<0.3$ & $<0.2$ & 44 \\
\hline B091 & 18.9 & 144 & 221 & 8.5 & $11 / 11 / 96$ & 2.2 & 733 & $<0.3$ & 1.72 & 190 \\
\hline B094 & 36.0 & 220 & 167 & 9 & $12 / 05 / 96$ & 2.9 & 1048 & 0.31 & 2.15 & 162 \\
\hline B115 & 30.3 & 63.5 & 165 & 10 & $04 / 28 / 97$ & 0.5 & 1098 & 1.26 & 5.78 & 460 \\
\hline B126 & 54.9 & 134 & 208 & 14 & $05 / 22 / 97$ & 1.9 & 1330 & 2.38 & 2.66 & 408 \\
\hline B139 & 64.0 & 39 & 141 & 3 & 08/07/97 & 1.4 & 2098 & 1.17 & 2.18 & 151 \\
\hline B142 & 6.3 & 135 & 198 & 14 & $09 / 02 / 97$ & 0.8 & 878 & $<0.3$ & $<0.2$ & 48 \\
\hline B151 & 53.6 & 70 & 162 & 3.5 & $11 / 07 / 97$ & 1.2 & 1454 & 2.67 & 1.83 & 64 \\
\hline B154 & 44.3 & 167 & 217 & 13 & $11 / 07 / 97$ & 2.6 & 1910 & 1.54 & 1.45 & 81 \\
\hline B157 & 53.6 & 72 & 160 & 5 & $11 / 07 / 97$ & NM & 1390 & $<0.3$ & 3.32 & 167 \\
\hline B160 & 42.3 & 190 & 224 & 13 & $12 / 02 / 97$ & 3.1 & 4739 & 6.56 & 3.89 & 286 \\
\hline B322 & 58.3 & 79 & 167 & 3 & 04/07/98 & 2.6 & 1166 & 0.63 & 1.99 & 66 \\
\hline B068 & 44.4 & 140 & 202 & 6 & 09/14/99 & 1.5 & 1449 & 2.15 & 3.93 & 218 \\
\hline B074 & 66.4 & 55.5 & 158 & 6 & 10/11/99 & 1.1 & 2739 & 3.18 & 6.14 & 259 \\
\hline $2000 D$ & 7.0 & 55.5 & NM & NM & 07/01/00 & NM & 1704 & 6.75 & 4.31 & 577 \\
\hline B260 & 49.5 & 70 & 158 & SA & 07/29/00 & 1 & 2497 & 4.71 & 5.06 & 216 \\
\hline B266 & 51.0 & 126 & 172 & 4 & 08/20/00 & 2.5 & 1587 & 5.91 & 2.81 & 172 \\
\hline B249 & 61.0 & 112.5 & 218 & 6 & $09 / 20 / 00$ & 1.1 & 1318 & 2.31 & 1.40 & 80 \\
\hline B500 & 62.7 & 186 & 222 & 17 & 08/01/02 & 3.2 & 1565 & 5.60 & 4.13 & 275 \\
\hline B503 & 67.8 & 35.5 & 130 & 3 & 08/01/02 & 1.5 & 1429 & 8.63 & 2.30 & 162 \\
\hline B497 & 69.0 & 99 & 167 & $5-8$ & 01/01/03 & 2.6 & 1204 & 11.85 & 1.48 & 79 \\
\hline
\end{tabular}

$\mathrm{NM}$ - indicates not measured.

SA - indicates sub-adult, age estimate approximately 4 to 8 years. 
Table 2. Correlation matrix presenting all the California sea lion variables analyzed in this study. Values represent the correlation coefficient for the two variables. (Significant correlations, $\mathrm{p}<0.01$, indicated with an asterisk).

\begin{tabular}{|c|c|c|c|c|c|c|c|c|c|c|}
\hline Variable & $\Sigma$ $\Sigma$ HBCD & इPBDE & MeOBDE & $\begin{array}{c}\text { DBP- } \\
\mathrm{Br}_{4} \mathrm{Cl}_{2}\end{array}$ & $\%$ Lipid & $\begin{array}{c}\text { Date } \\
\text { Stranded }\end{array}$ & Mass & Length & Age & $\begin{array}{c}\text { Blubber } \\
\text { Thickness }\end{array}$ \\
\hline PBDE & 0.261 & 1 & & & & & & & & \\
\hline MeOBDE & -0.101 & 0.083 & 1 & & & & & & & \\
\hline $\begin{array}{c}\text { DBP- } \\
\mathrm{Br}_{4} \mathrm{Cl}_{2}\end{array}$ & 0.027 & 0.160 & $0.680 *$ & 1 & & & & & & \\
\hline \% Lipid & 0.258 & 0.077 & -0.279 & -0.476 & 1 & & & & & \\
\hline $\begin{array}{c}\text { Date } \\
\text { Stranded }\end{array}$ & 0.800* & -0.024 & -0.176 & -0.258 & 0.419 & 1 & & & & \\
\hline Mass & -0.121 & -0.036 & 0.109 & 0.022 & -0.252 & -0.157 & 1 & & & \\
\hline Length & -0.174 & 0.033 & -0.358 & -0.151 & -0.025 & -0.138 & $0.510 *$ & 1 & & \\
\hline Age & -0.143 & -0.056 & 0.204 & 0.202 & -0.263 & -0.207 & $0.692 *$ & $0.619 *$ & 1 & \\
\hline $\begin{array}{l}\text { Blubber } \\
\text { Thickness }\end{array}$ & 0.104 & -0.052 & -0.241 & -0.236 & 0.490 & 0.033 & 0.415 & 0.503 & 0.271 & 1 \\
\hline
\end{tabular}




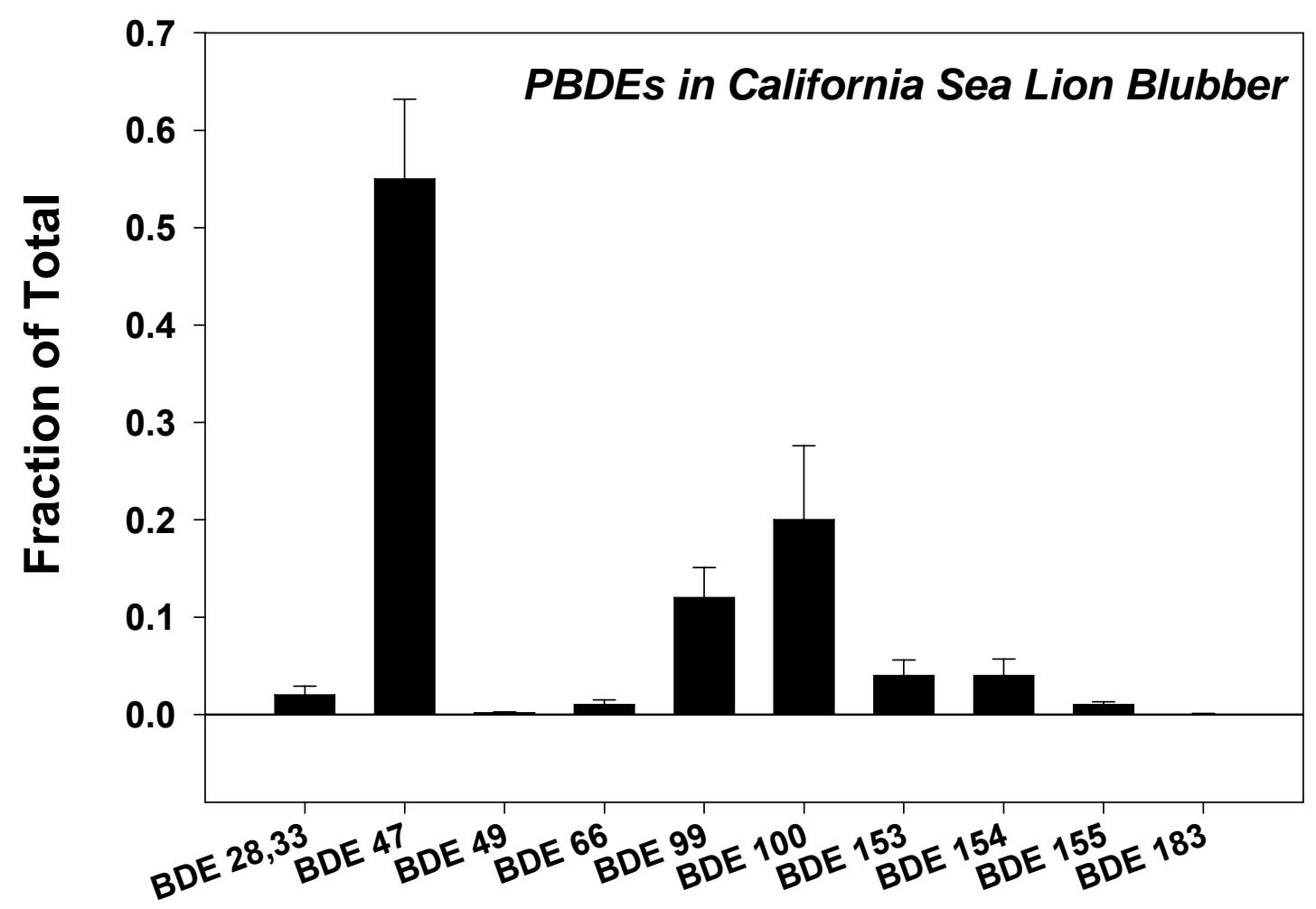

Figure 1. Average PBDE congener composition in California sea lion blubber samples $(n=26)$. Error bars represent the standard deviation. 


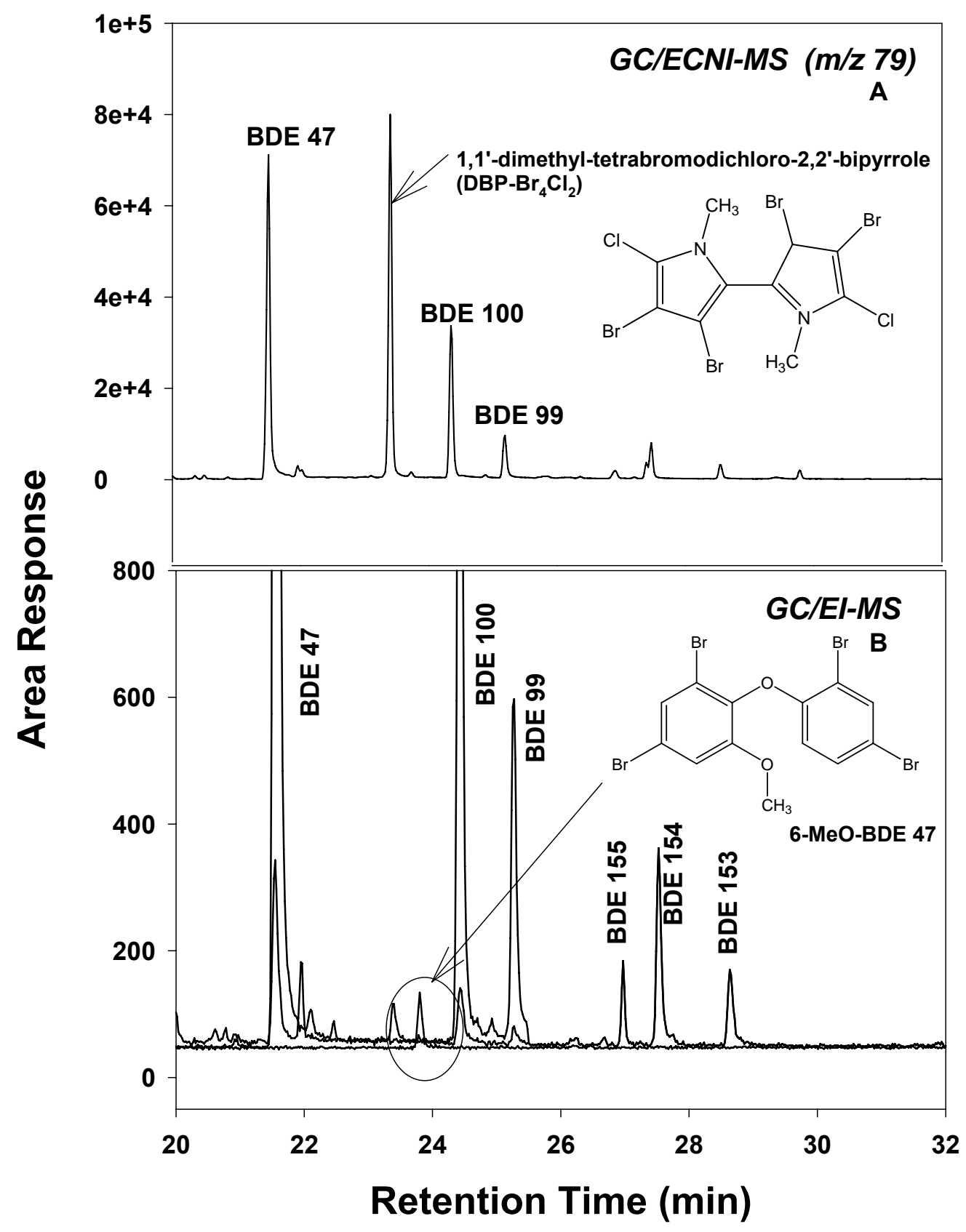

Figure 2. Chromatograms from the analysis of California sea lion blubber analyzed by GC/ECNI-MS in which a bipyrrole, referred to as DBP- $\mathrm{Br}_{4} \mathrm{Cl}_{2}$, is identified (A), and $\mathrm{GC} / \mathrm{EI}-\mathrm{MS}$ analysis to confirm the presence of MeO-BDEs (B). The GC/EI-MS chromatogram overlays the ion chromatograms for $\mathrm{m} / \mathrm{z} 486$ (BDE 47), $\mathrm{m} / \mathrm{z} 516$ (6-MeO-BDE 47), $\mathrm{m} / \mathrm{z} 404$ (BDEs 100 and 99) and m/z 484 (BDEs 155, 154, and 153). 


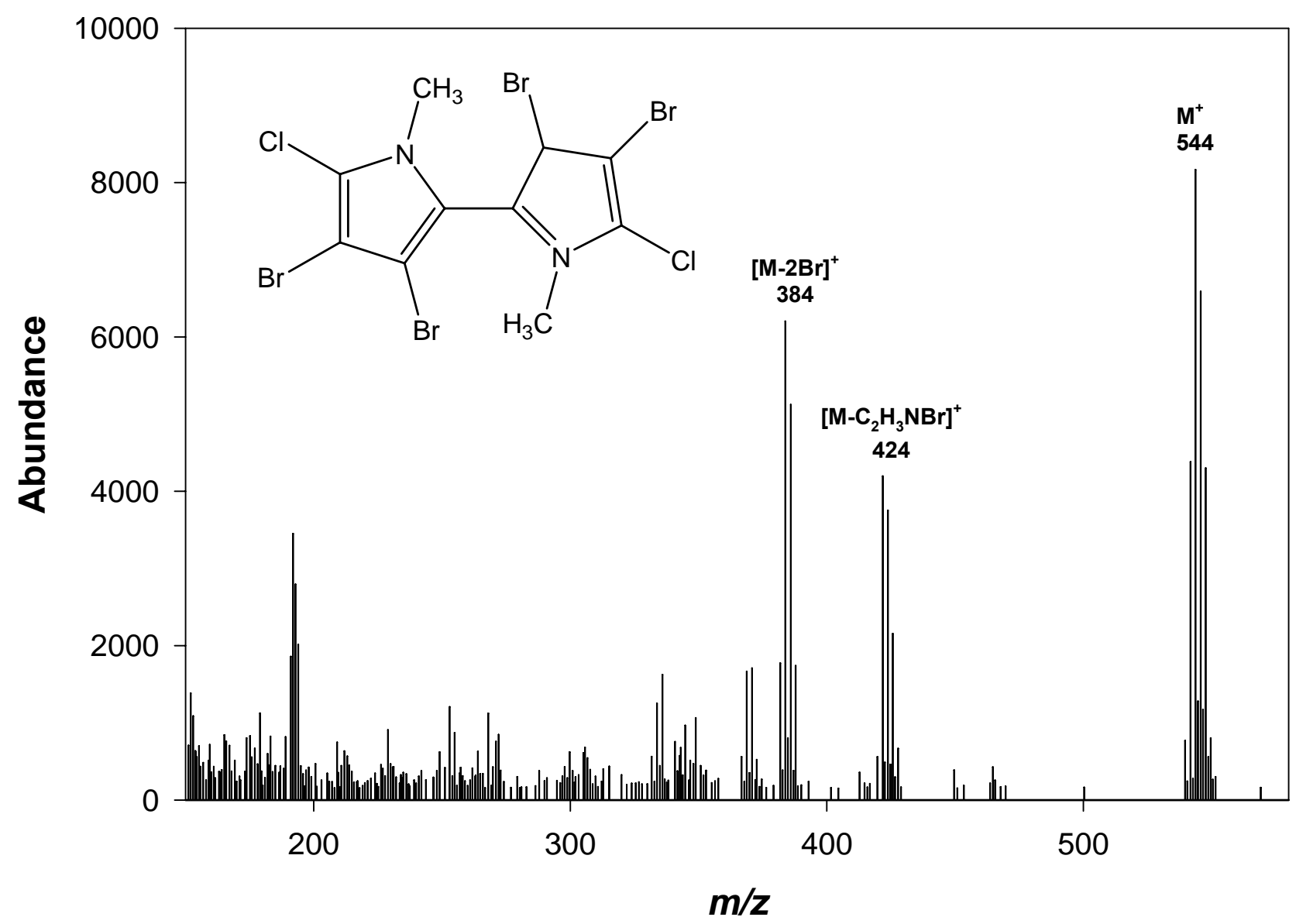

Figure 3. EI full mass spectrum of $\mathrm{DBP}-\mathrm{Br}_{4} \mathrm{Cl}_{2}$ in sea lion blubber extract. 


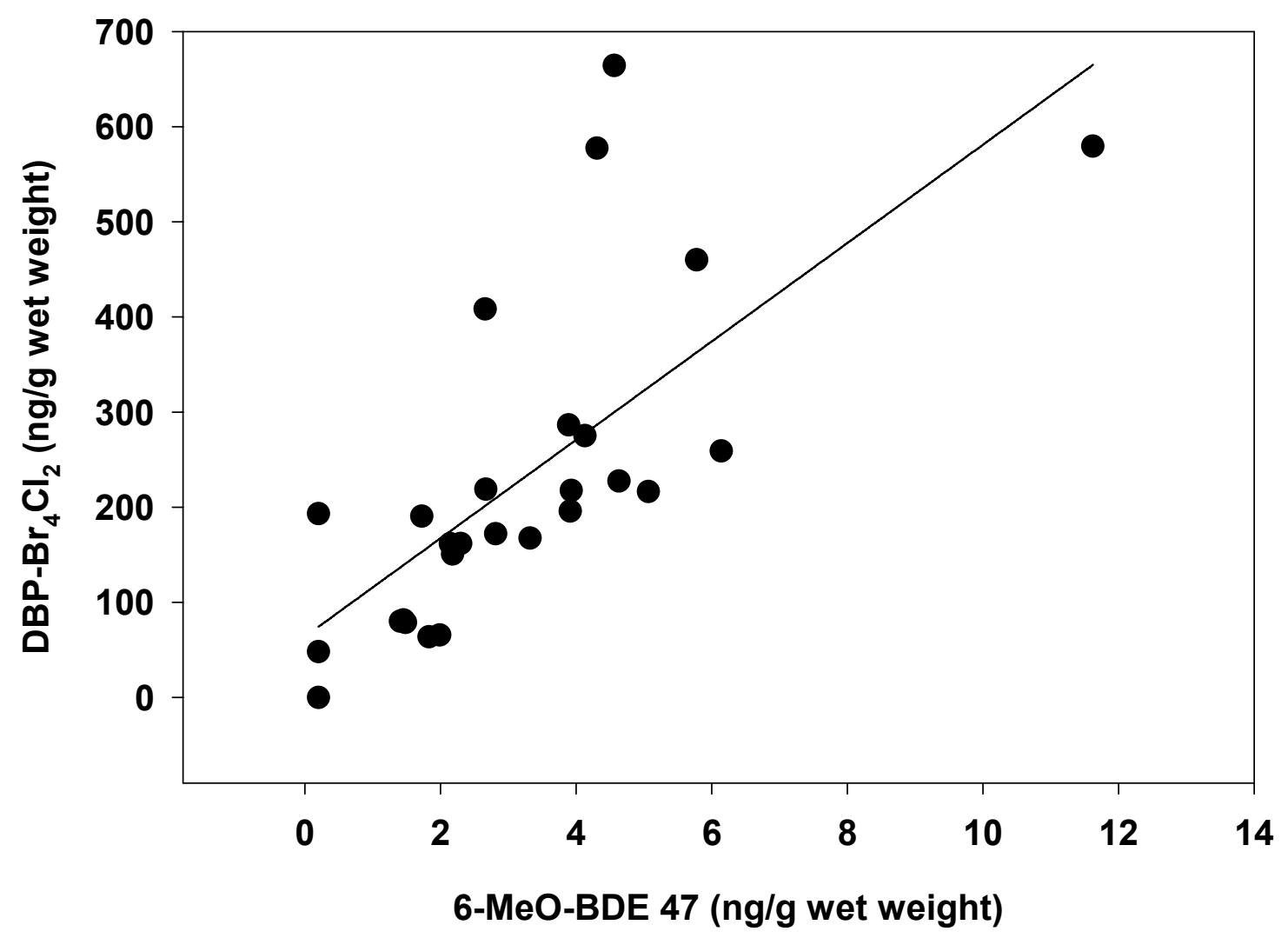

Figure 4. Correlation between 6-MeO-BDE 47 and 1,1'-dimethyl-3,3'4,4'-tetrabromo5,5'-dichloro-2,2'-bipyrrole ( $\left.\mathrm{DBP}-\mathrm{Br}_{4} \mathrm{Cl}_{2}\right)$ in California sea lion blubber. A value of 0.2 $\mathrm{ng} / \mathrm{g}$ wet weight was used for the three samples in which the concentration of 6-MeOBDE 47 was $<0.2 \mathrm{ng} / \mathrm{g}$. 


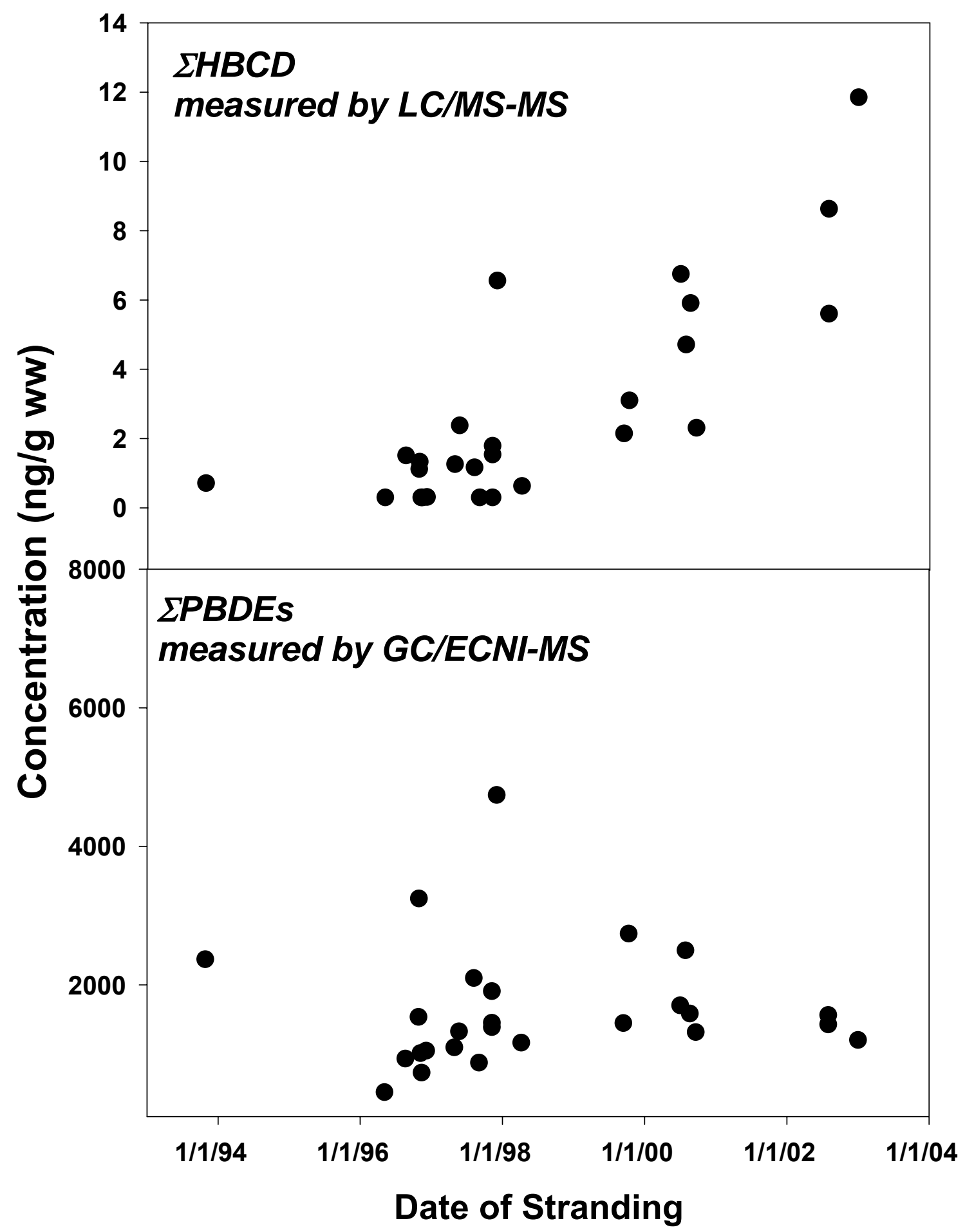

Figure 5. Concentration (ng/g wet weight) of $\Sigma \mathrm{HBCD}$ and $\Sigma$ PBDEs in blubber tissues recovered from stranded California sea lions. A value of $0.3 \mathrm{ng} / \mathrm{g}$ was used for the five samples in which HBCD was less than detection. 
Suppl. Table 1. Concentrations (ng/g wet mass) of PBDEs, HBCD, MeO-BDEs and a bromo- chloro- bipyrrole ( $\left.\mathrm{DBP}-\mathrm{Br}_{4} \mathrm{Cl}_{2}\right)$ in blubber of California sea lions with information on age, length, mass, lipid content and date of stranding.

\begin{tabular}{|c|c|c|c|c|c|c|}
\hline Sample & B052 & B059 & B081 & B084 & B088 & B091 \\
\hline$\%$ lipid & 13.25 & 79.17 & 60.54 & 8.16 & 55.38 & 18.93 \\
\hline Mass (kg) & 69 & 121.5 & 104 & 139 & 78 & 144 \\
\hline Length (cm) & 175 & 242.5 & 188 & 210 & 164 & 221 \\
\hline Age (years) & 8 & 12 & 4.5 & 11 & 7 & 8.5 \\
\hline Date of Stranding & 10/27/93 & 05/05/96 & $10 / 29 / 96$ & $10 / 26 / 96$ & $11 / 06 / 96$ & $11 / 11 / 96$ \\
\hline Congener & B052 & B059 & B081 & B084 & B088 & B091 \\
\hline BDE 17 & $<0.5$ & $<0.5$ & $<0.5$ & $<0.5$ & $<0.5$ & $<0.5$ \\
\hline BDE 25 & $<0.5$ & $<0.5$ & $<0.5$ & $<0.5$ & $<0.5$ & $<0.5$ \\
\hline BDE 28,33 & 51.2 & 7.8 & 28.8 & 19.5 & 20.2 & 10.7 \\
\hline BDE 30 & $<0.5$ & $<0.5$ & $<0.5$ & $<0.5$ & $<0.5$ & $<0.5$ \\
\hline BDE 47 & 1118 & 256 & 1337 & 651 & 670 & 442 \\
\hline BDE 49 & 1.67 & 1.73 & 3.22 & 1.99 & 0.00 & 1.03 \\
\hline BDE 66 & 19.2 & 4.54 & 10.0 & 8.1 & 10.6 & 5.6 \\
\hline BDE 71 & $<0.6$ & $<0.6$ & $<0.6$ & $<0.6$ & $<0.6$ & $<0.6$ \\
\hline BDE 75 & $<0.6$ & $<0.6$ & $<0.6$ & $<0.6$ & $<0.6$ & $<0.6$ \\
\hline BDE 85 & $<0.6$ & $<0.6$ & $<0.6$ & $<0.6$ & $<0.6$ & $<0.6$ \\
\hline BDE 99 & 310.4 & 57.8 & 215.9 & 165.7 & 110.7 & 98.4 \\
\hline BDE 100 & 604.8 & 82.4 & 1208 & 488.1 & 115.7 & 104.6 \\
\hline BDE 116 & $<0.6$ & $<0.6$ & $<0.6$ & $<0.6$ & $<0.6$ & $<0.6$ \\
\hline BDE 119 & $<0.5$ & $<0.5$ & $<0.5$ & $<0.5$ & $<0.5$ & $<0.5$ \\
\hline BDE 138 & $<0.6$ & $<0.6$ & $<0.6$ & $<0.6$ & $<0.6$ & $<0.6$ \\
\hline BDE 153 & 107.8 & 16.9 & 132.7 & 79.3 & 26.5 & 31.3 \\
\hline BDE 154 & 127.3 & 18.4 & 268.5 & 104.7 & 53.0 & 30.1 \\
\hline BDE 155 & 25.1 & 4.33 & 38.38 & 16.20 & 8.10 & 7.44 \\
\hline BDE 156 & $<0.7$ & $<0.7$ & $<0.7$ & $<0.7$ & $<0.7$ & $<0.7$ \\
\hline BDE 181 & $<0.7$ & $<0.7$ & $<0.7$ & $<0.7$ & $<0.7$ & $<0.7$ \\
\hline BDE 183 & 3.71 & 0.87 & 2.82 & 1.99 & 1.40 & 2.04 \\
\hline BDE 190 & $<1.0$ & $<1.0$ & $<1.0$ & $<1.0$ & $<1.0$ & $<1.0$ \\
\hline BDE 191 & $<0.7$ & $<0.7$ & $<0.7$ & $<0.7$ & $<0.7$ & $<0.7$ \\
\hline BDE 203 & $<0.8$ & $<0.8$ & $<0.8$ & $<0.8$ & $<0.8$ & $<0.8$ \\
\hline BDE 205 & $<1.0$ & $<1.0$ & $<1.0$ & $<1.0$ & $<1.0$ & $<1.0$ \\
\hline BDE 206 & $<1.0$ & $<1.0$ & $<1.0$ & $<1.0$ & $<1.0$ & $<1.0$ \\
\hline BDE 209 & $<1.0$ & $<1.0$ & $<1.0$ & $<1.0$ & $<1.0$ & $<1.0$ \\
\hline Total PBDE & 2370 & 451 & 3245 & 1537 & 1016 & 733 \\
\hline $\mathrm{DBP}-\mathrm{Br}_{4} \mathrm{Cl}_{2}$ & 664.3 & 195.9 & 193.2 & 218.9 & 44.24 & 190.4 \\
\hline 6-MeOBDE 47 & 4.56 & 3.91 & $<0.2$ & 2.67 & $<0.2$ & 1.72 \\
\hline$\alpha-H B C D$ & 0.71 & $<0.3$ & 1.33 & 1.12 & $<0.3$ & $<0.3$ \\
\hline$\beta-H B C D$ & $<0.3$ & $<0.3$ & $<0.3$ & $<0.3$ & $<0.3$ & $<0.3$ \\
\hline Y-HBCD & $<0.3$ & $<0.3$ & $<0.3$ & $<0.3$ & $<0.3$ & $<0.3$ \\
\hline
\end{tabular}


Suppl. Table 1 (con't). Concentrations (ng/g wet mass) of PBDEs, HBCD, MeO-BDEs and a brominated bipyrrole (DBP- $\mathrm{Br}_{4} \mathrm{Cl}_{2}$ ) in blubber of California sea lions with information on age, length, mass, lipid content and date of stranding.

\begin{tabular}{|c|c|c|c|c|c|c|c|}
\hline Sample & B094 & B115 & B126 & B139 & B142 & B078 & B151 \\
\hline$\%$ lipid & 35.98 & 30.27 & 54.92 & 63.96 & 6.32 & 20.17 & 53.59 \\
\hline Mass (kg) & 220 & 63.5 & 134 & 39 & 135 & 199.6 & 70 \\
\hline Length (cm) & 167 & 165 & 208 & 141 & 198 & 126 & 162 \\
\hline Age (years) & 9 & 10 & 14 & 3 & 14 & 11 & 3.5 \\
\hline Date of Stranding & $12 / 05 / 96$ & $04 / 28 / 97$ & $05 / 22 / 97$ & 08/07/97 & $09 / 02 / 97$ & 08/20/96 & $11 / 07 / 97$ \\
\hline Congener & B094 & B115 & B126 & B139 & B142 & B078 & B151 \\
\hline$\overline{\text { BDE } 17}$ & $<0.5$ & $<0.5$ & $<0.5$ & $<0.5$ & $<0.5$ & $<0.5$ & $<0.5$ \\
\hline BDE 25 & $<0.5$ & $<0.5$ & $<0.5$ & $<0.5$ & $<0.5$ & $<0.5$ & $<0.5$ \\
\hline BDE 28,33 & 26.0 & 40.2 & 34.1 & 65.6 & 6.5 & 22.0 & 27.2 \\
\hline BDE 30 & $<0.5$ & $<0.5$ & $<0.5$ & $<0.5$ & $<0.5$ & $<0.5$ & $<0.5$ \\
\hline BDE 47 & 557 & 659 & 729 & 1329 & 538 & 430 & 954 \\
\hline BDE 49 & 1.65 & 2.94 & 2.16 & 4.69 & $<0.3$ & 2.93 & 3.47 \\
\hline BDE 66 & 15.1 & 18.70 & 13.0 & 35.0 & 1.9 & 9.4 & 21.50 \\
\hline BDE 71 & $<0.6$ & $<0.6$ & $<0.6$ & $<0.6$ & $<0.6$ & $<0.6$ & $<0.6$ \\
\hline BDE 75 & $<0.6$ & $<0.6$ & $<0.6$ & $<0.6$ & $<0.6$ & $<0.6$ & $<0.6$ \\
\hline BDE 85 & $<0.6$ & $<0.6$ & $<0.6$ & $<0.6$ & $<0.6$ & $<0.6$ & $<0.6$ \\
\hline BDE 99 & 132.4 & 105.5 & 137.6 & 304.2 & 82.3 & 53.8 & 264.8 \\
\hline BDE 100 & 230.5 & 195.1 & 296 & 241.4 & 193.5 & 340.9 & 73.6 \\
\hline BDE 116 & $<0.6$ & $<0.6$ & $<0.6$ & $<0.6$ & $<0.6$ & $<0.6$ & $<0.6$ \\
\hline BDE 119 & $<0.5$ & $<0.5$ & $<0.5$ & $<0.5$ & $<0.5$ & $<0.5$ & $<0.5$ \\
\hline BDE 138 & $<0.6$ & $<0.6$ & $<0.6$ & $<0.6$ & $<0.6$ & $<0.6$ & $<0.6$ \\
\hline BDE 153 & 34.9 & 20.9 & 52.8 & 52.7 & 8.4 & 35.0 & 52.9 \\
\hline BDE 154 & 41.2 & 43.6 & 55.1 & 54.5 & 39.0 & 30.1 & 43.1 \\
\hline BDE 155 & 7.9 & 10.25 & 8.93 & 9.50 & 6.70 & 9.80 & 11.40 \\
\hline BDE 156 & $<0.7$ & $<0.7$ & $<0.7$ & $<0.7$ & $<0.7$ & $<0.7$ & $<0.7$ \\
\hline BDE 181 & $<0.7$ & $<0.7$ & $<0.7$ & $<0.7$ & $<0.7$ & $<0.7$ & $<0.7$ \\
\hline BDE 183 & 0.87 & 1.44 & 1.55 & 1.16 & 2.06 & 2.26 & 1.41 \\
\hline BDE 190 & $<1.0$ & $<1.0$ & $<1.0$ & $<1.0$ & $<1.0$ & $<1.0$ & $<1.0$ \\
\hline BDE 191 & $<0.7$ & $<0.7$ & $<0.7$ & $<0.7$ & $<0.7$ & $<0.7$ & $<0.7$ \\
\hline BDE 203 & $<0.8$ & $<0.8$ & $<0.8$ & $<0.8$ & $<0.8$ & $<0.8$ & $<0.8$ \\
\hline BDE 205 & $<1.0$ & $<1.0$ & $<1.0$ & $<1.0$ & $<1.0$ & $<1.0$ & $<1.0$ \\
\hline BDE 206 & $<1.0$ & $<1.0$ & $<1.0$ & $<1.0$ & $<1.0$ & $<1.0$ & $<1.0$ \\
\hline BDE 209 & $<1.0$ & $<1.0$ & $<1.0$ & $<1.0$ & $<1.0$ & $<1.0$ & $<1.0$ \\
\hline Total PBDE & 1048 & 1098 & 1330 & 2098 & 878 & 936 & 1454 \\
\hline DBP-Br ${ }_{4} \mathrm{Cl}_{2}$ & 161.6 & 460.1 & 408.3 & 150.8 & 48.10 & 579.3 & 53.60 \\
\hline 6-MeOBDE 47 & 2.15 & 5.78 & 2.66 & 2.18 & $<0.2$ & 11.62 & 1.83 \\
\hline$\alpha-H B C D$ & 0.31 & 1.26 & 2.38 & 1.17 & $<0.3$ & 0.94 & 1.79 \\
\hline$\beta-H B C D$ & $<0.3$ & $<0.3$ & $<0.3$ & $<0.3$ & $<0.3$ & 0.58 & 0.87 \\
\hline Y-HBCD & $<0.3$ & $<0.3$ & $<0.3$ & $<0.3$ & $<0.3$ & $<0.3$ & $<0.3$ \\
\hline Total HBCD & 0.31 & 1.26 & 2.38 & 1.17 & $<0.3$ & 1.51 & 2.67 \\
\hline
\end{tabular}


Suppl. Table 1 (con't). Concentrations (ng/g wet mass) of PBDEs, HBCD, MeO-BDEs and a brominated bipyrrole (DBP- $\left.\mathrm{Br}_{4} \mathrm{Cl}_{2}\right)$ in blubber of California sea lions with information on age, length, mass, lipid content and date of stranding.

\begin{tabular}{|c|c|c|c|c|c|c|c|}
\hline Sample & B154 & B157 & B160 & B322 & B068 & B074 & 2000D \\
\hline$\%$ lipid & 44.29 & 53.56 & 42.34 & 58.31 & 44.36 & 66.35 & 7.03 \\
\hline Mass (kg) & 167 & 72 & 190 & 79 & 140 & 55.5 & NM \\
\hline Length (cm) & 217 & 160 & 224 & 167 & 202 & 158 & NM \\
\hline Age (years) & 13 & 5 & 13 & 3 & 6 & 6 & NM \\
\hline Date of Stranding & $11 / 07 / 97$ & $11 / 07 / 97$ & $12 / 02 / 97$ & 04/07/98 & 09/14/99 & $10 / 11 / 99$ & $07 / 01 / 00$ \\
\hline Congener & B154 & B157 & B160 & B322 & B068 & B074 & 2000D \\
\hline BDE 17 & $<0.5$ & $<0.5$ & $<0.5$ & $<0.5$ & $<0.5$ & $<0.5$ & $<0.5$ \\
\hline BDE 25 & $<0.5$ & $<0.5$ & $<0.5$ & $<0.5$ & $<0.5$ & $<0.5$ & $<0.5$ \\
\hline BDE 28,33 & 25.7 & 48.4 & 90.6 & 25.8 & 42.2 & 75.4 & 47.5 \\
\hline BDE 30 & $<0.5$ & $<0.5$ & $<0.5$ & $<0.5$ & $<0.5$ & $<0.5$ & $<0.5$ \\
\hline BDE 47 & 905 & 797 & 1875 & 660 & 756 & 1604 & 743 \\
\hline BDE 49 & 2.62 & 4.69 & 8.05 & 1.83 & 1.35 & 5.65 & 1.58 \\
\hline BDE 66 & 15.22 & 23.79 & 90.28 & 11.49 & 13.57 & 43.51 & 16.7 \\
\hline BDE 71 & $<0.6$ & $<0.6$ & $<0.6$ & $<0.6$ & $<0.6$ & $<0.6$ & $<0.6$ \\
\hline BDE 75 & $<0.6$ & $<0.6$ & $<0.6$ & $<0.6$ & $<0.6$ & $<0.6$ & $<0.6$ \\
\hline BDE 85 & $<0.6$ & $<0.6$ & $<0.6$ & $<0.6$ & $<0.6$ & $<0.6$ & $<0.6$ \\
\hline BDE 99 & 240.2 & 154.9 & 803.7 & 129.5 & 198.3 & 463.8 & 244.3 \\
\hline BDE 100 & 436.4 & 281.0 & 1067.3 & 245.6 & 271.9 & 336.9 & 453.8 \\
\hline BDE 116 & $<0.6$ & $<0.6$ & $<0.6$ & $<0.6$ & $<0.6$ & $<0.6$ & $<0.6$ \\
\hline BDE 119 & $<0.5$ & $<0.5$ & $<0.5$ & $<0.5$ & $<0.5$ & $<0.5$ & $<0.5$ \\
\hline BDE 138 & $<0.6$ & $<0.6$ & $<0.6$ & $<0.6$ & $<0.6$ & $<0.6$ & $<0.6$ \\
\hline BDE 153 & 138.0 & 31.3 & 288.2 & 42.3 & 92.3 & 95.6 & 73.5 \\
\hline BDE 154 & 119.5 & 39.1 & 429.7 & 40.7 & 57.1 & 94.0 & 99.5 \\
\hline BDE 155 & 16.76 & 8.77 & 71.23 & 7.36 & 11.02 & 16.88 & 21.8 \\
\hline BDE 156 & $<0.7$ & $<0.7$ & $<0.7$ & $<0.7$ & $<0.7$ & $<0.7$ & $<0.7$ \\
\hline BDE 181 & $<0.7$ & $<0.7$ & $<0.7$ & $<0.7$ & $<0.7$ & $<0.7$ & $<0.7$ \\
\hline BDE 183 & 10.14 & 0.70 & 15.31 & 1.17 & 6.04 & 3.74 & 2.82 \\
\hline BDE 190 & $<1.0$ & $<1.0$ & $<1.0$ & $<1.0$ & $<1.0$ & $<1.0$ & $<1.0$ \\
\hline BDE 191 & $<0.7$ & $<0.7$ & $<0.7$ & $<0.7$ & $<0.7$ & $<0.7$ & $<0.7$ \\
\hline BDE 203 & $<0.8$ & $<0.8$ & $<0.8$ & $<0.8$ & $<0.8$ & $<0.8$ & $<0.8$ \\
\hline BDE 205 & $<1.0$ & $<1.0$ & $<1.0$ & $<1.0$ & $<1.0$ & $<1.0$ & $<1.0$ \\
\hline BDE 206 & $<1.0$ & $<1.0$ & $<1.0$ & $<1.0$ & $<1.0$ & $<1.0$ & $<1.0$ \\
\hline BDE 209 & $<1.0$ & $<1.0$ & $<1.0$ & $<1.0$ & $<1.0$ & $<1.0$ & $<1.0$ \\
\hline Total PBDE & 1910 & 1390 & 4739 & 1166 & 1449 & 2739 & 1704 \\
\hline DBP- $-\mathrm{Br}_{4} \mathrm{Cl}_{2}$ & 81.36 & 167.5 & 286.3 & 65.68 & 217.6 & 243.3 & 577.3 \\
\hline 6-MeOBDE 47 & 1.45 & 3.32 & 3.89 & 1.99 & 3.93 & 6.14 & 4.31 \\
\hline$\alpha-H B C D$ & 1.54 & $<0.3$ & 6.26 & 0.63 & 2.15 & 3.18 & 6.75 \\
\hline$\beta-H B C D$ & $<0.3$ & $<0.3$ & 0.30 & $<0.3$ & $<0.3$ & $<0.3$ & $<0.3$ \\
\hline Y-HBCD & $<0.3$ & $<0.3$ & $<0.3$ & $<0.3$ & $<0.3$ & $<0.3$ & $<0.3$ \\
\hline Total HBCD & 1.54 & $<0.3$ & 6.56 & 0.63 & 2.15 & 3.18 & 6.75 \\
\hline
\end{tabular}


Suppl. Table 1 (con't). Concentrations (ng/g wet mass) of PBDEs, HBCD, MeO-BDEs and a brominated bipyrrole (DBP- $\mathrm{Br}_{4} \mathrm{Cl}_{2}$ ) in blubber of California sea lions with information on age, length, mass, lipid content and date of stranding.

\begin{tabular}{|c|c|c|c|c|c|c|}
\hline Sample & B260 & B266 & B249 & B500 & B503 & B497 \\
\hline$\%$ lipid & 49.5 & 50.99 & 60.97 & 62.68 & 67.83 & 69.04 \\
\hline Mass (kg) & 70 & 126 & 112.5 & 186 & 35.5 & 99 \\
\hline Length (cm) & 158 & 172 & 218 & 222 & 130 & 167 \\
\hline Age (years) & Sub-adult & 4 & 6 & Adult & 3 & $5-8$ \\
\hline Date of Stranding & 07/29/00 & $08 / 20 / 00$ & $09 / 20 / 00$ & 08/01/02 & 08/01/02 & 01/03/03 \\
\hline Congener & B260 & B266 & B249 & B500 & B503 & B497 \\
\hline BDE 17 & $<0.5$ & $<0.5$ & $<0.5$ & $<0.5$ & $<0.5$ & $<0.5$ \\
\hline BDE 25 & $<0.5$ & $<0.5$ & $<0.5$ & $<0.5$ & $<0.5$ & $<0.5$ \\
\hline BDE 28,33 & 97.6 & 40.3 & 59.3 & 31.3 & 57.7 & 30.7 \\
\hline BDE 30 & $<0.5$ & $<0.5$ & $<0.5$ & $<0.5$ & $<0.5$ & $<0.5$ \\
\hline BDE 47 & 1417 & 869 & 803 & 869 & 1018 & 791 \\
\hline BDE 49 & 3.93 & 1.35 & 2.54 & 2.30 & 2.93 & 3.23 \\
\hline BDE 66 & 35.3 & 14.4 & 16.22 & 13.9 & 27.3 & 13.3 \\
\hline BDE 71 & $<0.6$ & $<0.6$ & $<0.6$ & $<0.6$ & $<0.6$ & $<0.6$ \\
\hline BDE 75 & $<0.6$ & $<0.6$ & $<0.6$ & $<0.6$ & $<0.6$ & $<0.6$ \\
\hline BDE 85 & $<0.6$ & $<0.6$ & $<0.6$ & $<0.6$ & $<0.6$ & $<0.6$ \\
\hline BDE 99 & 254.4 & 217.8 & 114.2 & 201.0 & 141.2 & 124.0 \\
\hline BDE 100 & 530.1 & 262.8 & 250.2 & 318.5 & 133.7 & 169.6 \\
\hline BDE 116 & $<0.6$ & $<0.6$ & $<0.6$ & $<0.6$ & $<0.6$ & $<0.6$ \\
\hline BDE 119 & $<0.5$ & $<0.5$ & $<0.5$ & $<0.5$ & $<0.5$ & $<0.5$ \\
\hline BDE 138 & $<0.6$ & $<0.6$ & $<0.6$ & $<0.6$ & $<0.6$ & $<0.6$ \\
\hline BDE 153 & 63.5 & 107.1 & 33.2 & 52.6 & 22.1 & 29.1 \\
\hline BDE 154 & 81.7 & 58.1 & 31.4 & 61.5 & 22.7 & 36.0 \\
\hline BDE 155 & 12.94 & 12.11 & 6.91 & 12.99 & 4.04 & 6.86 \\
\hline BDE 156 & $<0.7$ & $<0.7$ & $<0.7$ & $<0.7$ & $<0.7$ & $<0.7$ \\
\hline BDE 181 & $<0.7$ & $<0.7$ & $<0.7$ & $<0.7$ & $<0.7$ & $<0.7$ \\
\hline BDE 183 & 1.26 & 4.12 & 1.43 & 1.21 & $<0.5$ & 0.48 \\
\hline BDE 190 & $<1.0$ & $<1.0$ & $<1.0$ & $<1.0$ & $<1.0$ & $<1.0$ \\
\hline BDE 191 & $<0.7$ & $<0.7$ & $<0.7$ & $<0.7$ & $<0.7$ & $<0.7$ \\
\hline BDE 203 & $<0.8$ & $<0.8$ & $<0.8$ & $<0.8$ & $<0.8$ & $<0.8$ \\
\hline BDE 205 & $<1.0$ & $<1.0$ & $<1.0$ & $<1.0$ & $<1.0$ & $<1.0$ \\
\hline BDE 206 & $<1.0$ & $<1.0$ & $<1.0$ & $<1.0$ & $<1.0$ & $<1.0$ \\
\hline BDE 209 & $<1.0$ & $<1.0$ & $<1.0$ & $<1.0$ & $<1.0$ & $<1.0$ \\
\hline Total PBDE & 2497 & 1587 & 1318 & 1565 & 1429 & 1204 \\
\hline $\mathrm{DBP}-\mathrm{Br}_{4} \mathrm{Cl}_{2}$ & 216.4 & 171.8 & 80.14 & 275.1 & 161.8 & 78.69 \\
\hline 6-MeOBDE 47 & 5.06 & 2.81 & 1.40 & 4.13 & 2.30 & 1.48 \\
\hline$\alpha-H B C D$ & 4.71 & 5.91 & 2.31 & 5.60 & 8.63 & 11.85 \\
\hline$\beta-H B C D$ & $<0.3$ & $<0.3$ & $<0.3$ & $<0.3$ & $<0.3$ & $<0.3$ \\
\hline$Y-H B C D$ & $<0.3$ & $<0.3$ & $<0.3$ & $<0.3$ & $<0.3$ & $<0.3$ \\
\hline Total HBCD & 4.71 & 5.91 & 2.31 & 5.60 & 8.63 & 11.85 \\
\hline
\end{tabular}




\section{Reference List}

1. Stapleton, H. M.; Baker, J. E. Comparing polybrominated diphenyl ether and polychlorinated biphenyl bioaccumulation in a food web in Grand Traverse Bay, Lake Michigan. Archives of Environmental Contamination and Toxicology 2003, 45 (2), 227-234.

2. Voorspoels, S.; Covaci, A.; Schepens, P. Polybrominated diphenyl ethers in marine species from the Belgian North Sea and the Western Scheidt Estuary: Levels, profiles, and distribution. Environmental Science \& Technology 2003, 37 (19), 4348-4357.

3. Wolkers, H.; van Bavel, B.; Derocher, A. E.; Wiig, O.; Kovacs, K. M.; Lydersen, C.; Lindstrom, G. Congener-specific accumulation and food chain transfer of polybrominated diphenyl ethers in two Arctic food chains.

Environmental Science \& Technology 2004, 38 (6), 1667-1674.

4. Morris, S.; Allchin, C. R.; Zegers, B. N.; Haftka, J. J. H.; Boon, J. P.; Belpaire, C.; Leonards, P. E. G.; Van Leeuwen, S. P. J.; de Boer, J. Distributon and fate of HBCD and TBBPA brominated flame retardants in north sea estuaries and aquatic food webs. Environmental Science \& Technology 2004, 38 (21), 5497-5504.

5. Remberger, M.; Sternbeck, J.; Palm, A.; Kaj, L.; Stromberg, K.; BrorstromLunden, E. The environmental occurrence of hexabromocyclododecane in Sweden. Chemosphere 2004, 54 (1), 9-21.

6. Tomy, G. T.; Budakowski, W.; Halldorson, T.; Whittle, D. M.; Keir, M. J.; Marvin, C.; Macinnis, G.; Alaee, M. Biomagnification of alpha- and gamma-hexabromocyclododecane isomers in a Lake Ontario food web. Environmental Science \& Technology 2004, 38 (8), 2298-2303.

7. WHO Environmental Health Criteria 162: Brominated Diphenyl Ethers; World Health Organization: Geneva, 1994.

8. de Wit, C. A. An overview of brominated flame retardants in the environment. Chemosphere 2002, 46 (5), 583-624.

9. Tittlemier, S. A.; Simon, M.; Jarman, W. M.; Elliott, J. E.; Norstrom, R. J. Identification of a novel $\mathrm{C} 10 \mathrm{H} 6 \mathrm{~N} 2 \mathrm{Br} 4 \mathrm{Cl} 2$ heterocyclic compound in seabird eggs. A bioaccumulating marine natural product? Environmental Science \& Technology 1999, 33 (1), 26-33.

10. Vetter, W.; Stoll, E.; Garson, M. J.; Fahey, S. J.; Gaus, C.; Muller, J. F. Sponge halogenated natural products found at parts-per-million levels in marine mammals. Environmental Toxicology and Chemistry 2002, 21 (10), 20142019. 
11. Vetter, W.; Scholz, E.; Gaus, C.; Muller, J. F.; Haynes, D. Anthropogenic and natural organohalogen compounds in blubber of dolphins and dugongs (Dugong dugon) from northeastern Australia. Archives of Environmental Contamination and Toxicology 2001, 41 (2), 221-231.

12. Reddy, C. M.; Xu, L.; O'Neil, G. W.; Nelson, R. K.; Eglinton, T. I.; Faulkner, D. J.; Norstrom, R.; Ross, P. S.; Tittlemier, S. A. Radiocarbon evidence for a naturally produced, bioaccumulating halogenated organic compound. Environmental Science \& Technology 2004, 38 (7), 1992-1997.

13. Teuten, E. L.; Xu, L.; Reddy, C. M. Two abundant bioaccumulated halogenated compounds are natural products. Science 2005, 307 (5711), 917-920.

14. Haglund, P. S.; Zook, D. R.; Buser, H. R.; Hu, J. W. Identification and quantification of polybrominated diphenyl ethers and methoxypolybrominated diphenyl ethers in Baltic biota. Environmental Science \& Technology 1997, 31 (11), 3281-3287.

15. Marsh, G.; Athanasiadou, M.; Bergman, A.; Asplund, L. Identification of hydroxylated and methoxylated polybrominated diphenyl ethers in Baltic Sea salmon (Salmo salar) blood. Environmental Science \& Technology 2004, 38 (1), 10-18.

16. Pettersson, A.; van Bavel, B.; Engwall, M.; Jimenez, B. Polybrominated diphenylethers and methoxylated tetrabromodiphenylethers in cetaceans from the Mediterranean Sea. Archives of Environmental Contamination and Toxicology 2004, 47 (4), 542-550.

17. Ikonomou, M. G.; Rayne, S.; Addison, R. F. Exponential increases of the brominated flame retardants, polybrominated diphenyl ethers, in the Canadian arctic from 1981 to 2000 . Environmental Science \& Technology 2002, 36 (9), 1886-1892.

18. Norstrom, R. J.; Simon, M.; Moisey, J.; Wakeford, B.; Weseloh, D. V. C. Geographical distribution (2000) and temporal trends (1981-2000) of brominated diphenyl ethers in Great Lakes herring gull eggs. Environmental Science \& Technology 2002, 36 (22), 4783-4789.

19. She, J. W.; Petreas, M.; Winkler, J.; Visita, P.; McKinney, M.; Kopec, D. PBDEs in the San Francisco Bay Area: measurements in harbor seal blubber and human breast adipose tissue. Chemosphere 2002, 46 (5), 697-707.

20. Noren, K.; Meironyte, D. Certain organochlorine and organobromine contaminants in Swedish human milk in perspective of past 20-30 years. Chemosphere 2000, 40 (9-11), 1111-1123.

21. Internet Communication 2005. 
22. Tullo, A. Flame Retardant Phaseout. Chemical and Engineering News 2003, 81 (45), 13.

23. Prevedouros, K.; Jones, K. C.; Sweetman, A. J. Estimation of the production, consumption, and atmospheric emissions of pentabrominated diphenyl ether in Europe between 1970 and 2000. Environmental Science \& Technology 2004, 38 (12), 3224-3231.

24. Sellstrom, U.; Bignert, A.; Kierkegaard, A.; Haggberg, L.; de Wit, C. A.; Olsson, M.; Jansson, B. Temporal trend studies on tetra-and pentabrominated diphenyl ethers and hexabromocyclododecane in guillemot egg from the Baltic Sea. Environmental Science \& Technology 2003, 37 (24), 54965501.

25. Bergman, A. BFRs with focus on Environmental Fate and Risks of Decabromodiphenyl ether and Hexabromocyclododecane. 2004; pp 1-5.

26. Kajiwara, N.; Kannan, K.; Muraoka, M.; Watanabe, M.; Takahashi, S.; Gulland, F.; Olsen, H.; Blankenship, A. L.; Jones, P. D.; Tanabe, S.; Giesy, J. P. Organochlorine pesticides, polychlorinated biphenyls, and butyltin compounds in blubber and livers of stranded California sea lions, elephant seals, and harbor seals from coastal California, USA. Archives of Environmental Contamination and Toxicology 2001, 41 (1), 90-99.

27. Debier, C.; Ylitalo, G. M.; Weise, M.; Gulland, F.; Costa, D. P.; Le Boeuf, B. J.; de Tillesse, T.; Larondelle, Y. PCBs and DDT in the serum of juvenile California sea lions: associations with vitamins $\mathrm{A}$ and $\mathrm{E}$ and thyroid hormones. Environmental Pollution 2005, 134 (2), 323-332.

28. Ylitalo, G. M. The role of organochlorines in cancer-associated mortality in California sea lions (Zalophus californianus). Marine Pollution Bulletin 2005, 50 (1), 30-39.

29. Zeisler, R.; Langland, J. K.; Harrison, S. H. Cryogenic Homogenization of Biological Tissues. Analytical Chemistry 1983, 55 (14), 2431-2434.

30. Geraci, J. R.; Lounsbury, V. J. Marine Mammals Ashore, A Field Guide for Strandings; Texas A\&M University Sea Grant College Program: College Station, TX, 1993.

31. Rosas, F. C. W.; Haimovici, M.; Pinedo, M. C. Age and Growth of the SouthAmerican Sea Lion, Otaria-Flavescens (Shaw, 1800), in Southern Brazil. Journal of Mammalogy 1993, 74 (1), 141-147.

32. Marsh, G.; Stenutz, R.; Bergman, A. Synthesis of hydroxylated and methoxylated polybrominated diphenyl ethers - Natural products and potential polybrominated diphenyl ether metabolites. European Journal of Organic Chemistry 2003, (14), 2566-2576. 
33. Tittlemier, S. A.; Fisk, A. T.; Hobson, K. A.; Norstrom, R. J. Examination of the bioaccumulation of halogenated dimethyl bipyrroles in an Arctic marine food web using stable nitrogen isotope analysis. Environmental Pollution 2002, 116 (1), 85-93.

34. Bjorklund, J.; Tollback, P.; Ostman, C. Mass spectrometric characteristics of decabromodiphenyl ether and the application of isotopic dilution in the electron capture negative ionization mode for the analysis of polybrominated diphenyl ethers. Journal of Mass Spectrometry 2003, 38 (4), 394-400.

35. Budakowski, W.; Tomy, G. Congener-specific analysis of hexabromocyclododecane by high-performance liquid chromatography/electrospray tandem mass spectrometry. Rapid Communications in Mass Spectrometry 2003, 17 (13), 1399-1404.

36. Zhu, L. Y.; Hites, R. A. Determination of polybrominated diphenyl ethers in environmental standard reference materials. Analytical Chemistry 2003, 75 (23), 6696-6700.

37. Stapleton, H. M.; Schnatz, M. M.; Wise, S. A. Measurement of polybrominated diphenyl ethers in environmental matrix standard reference materials. Organohalogen Compd. 2004, 66, 3696-3699.

38. Kannan, K.; Kajiwara, N.; Le Boeuf, B. J.; Tanabe, S. Organochlorine pesticides and polychlorinated biphenyls in California sea lions. Environmental Pollution 2004, 131 (3), 425-434.

39. Zegers, B.; Mets, A.; van Bommel, R.; Minkenberg, C.; Hamers, T.; Kamstra, J. H.; Learmont, J. A.; Vazquez, B. S.; Pierce, G.; Reid, B.; Patterson, T.; Rogan, E.; Murphy, S.; Addink, M.; Hartmann, M. G.; Smeenk, C.; Dabin, W.; Ridoux, V.; Gonzalez, A. F.; Lopez, A.; Jauniaux, T.; Boon, J. P. Stereo-isomer specific bioaccumulation of hexabromocyclododecane (HBCD) in marine mammals. 2005; pp 411-414.

40. Eljarrat, E.; de la Cal, A.; Raldua, D.; Duran, C.; Barcelo, D. Occurrence and bioavailability of polybrominated diphenyl ethers and hexabromocyclododecane in sediment and fish from the Cinca River, a tributary of the Ebro River (Spain). Environmental Science \& Technology 2004, 38 (9), 2603-2608.

41. Lindberg, P.; Sellstrom, U.; Haggberg, L.; de Wit, C. A. Higher brominated diphenyl ethers and hexabromocyclododecane found in eggs of peregrine falcons (Falco peregrinus) breeding in Sweden. Environmental Science \& Technology 2004, 38 (1), 93-96.

42. Rayne, S.; Ikonomou, M. G.; Ross, P. S.; Ellis, G. M.; Barrett-Lennard, L. G. PBDEs, PBBs, and PCNs in three communities of free-ranging killer 
whales (Orcinus orca) from the northeastern Pacific Ocean. Environmental Science \& Technology 2004, 38 (16), 4293-4299.

43. Kajiwara, N.; Ueno, D.; Takahashi, A.; Baba, N.; Tanabe, S. Polybrominated diphenyl ethers and organochlorines in archived northern fur seal samples from the Pacific coast of Japan, 1972-1998. Environmental Science \& Technology 2004, 38 (14), 3804-3809.

44. Kalantzi, O. I.; Hall, A. J.; Thomas, G. O.; Jones, K. C. Polybrominated diphenyl ethers and selected organochlorine chemicals in grey seals (Halichoerus grypus) in the North Sea. Chemosphere 2005, 58 (3), 345-354.

45. Tuerk, K. J. S.; Kucklick, J. R.; Becker, P. R.; Stapleton, H. M.; Baker, J. E. Persistent organic pollutants in two dolphin species with focus on toxaphene and polybrominated diphenyl ethers. Environmental Science \& Technology 2005, 39 (3), 692-698.

46. Law, R. J.; Allchin, C. R.; Bennett, M. E.; Morris, S.; Rogan, E. Polybrominated diphenyl ethers in two species of marine top predators from England and Wales. Chemosphere 2002, 46 (5), 673-681.

47. Sjodin, A.; Jakobsson, E.; Kierkegaard, A.; Marsh, G.; Sellstrom, U. Gas chromatographic identification and quantification of polybrominated diphenyl ethers in a commercial product, Bromkal 70-5DE. Journal of Chromatography A 1998, 822 (1), 83-89.

48. Stapleton, H. M.; Letcher, R. J.; Baker, J. E. Debromination of polyhrominated diphenyl ether congeners BDE 99 and BDE 183 in the intestinal tract of the common carp (Cyprinus carpio). Environmental Science \& Technology 2004, 38 (4), 1054-1061.

49. Hakk, H.; Letcher, R. J. Metabolism in the toxicokinetics and fate of brominated flame retardants - a review. Environment International 2003, 29 (6), 801828.

50. Orn, U.; Klasson-Wehler, E. Metabolism of 2,2 ',4,4 '-tetrabromodiphenyl ether in rat and mouse. Xenobiotica 1998, 28 (2), 199-211.

51. Letcher, R. J.; Klasson-Wehler, E.; Bergman, A. Methyl Sulfone and Hydroxylated Metabolites of Polychlorinated Biphenyls. In The Handbook of Environmental Chemistry, Paasivirta, J., Ed.; Springer-Verlag: Berlin Heidelberg, 2000; pp 315-359.

52. Malmvarn, A.; Marsh, G.; Kautsky, L.; Athanasiadou, M.; Bergman, A.; Asplund, L. Hydroxylated and Methoxylated Brominated Diphenyl Ethers in the Red Algae Ceramium tenuicorne adn Blue Mussels from the Baltic Sea. Environmental Science \& Technology 2005, 39 (ASAP alerts). 
53. Betts, K. S. Rapidly rising PBDE levels in North America. Environmental Science \& Technology 2002, 36 (3), 50A-52A.

54. Hites, R. A. Polyhrominated diphenyl ethers in the environment and in people: A meta-analysis of concentrations. Environmental Science \& Technology 2004, 38 (4), 945-956.

55. Sellstrom, U.; Kierkegaard, A.; de Wit, C.; Jansson, B. Polybrominated diphenyl ethers and hexabromocyclododecane in sediment and fish from a Swedish river. Environmental Toxicology and Chemistry 1998, 17 (6), 1065-1072.

56. Darnerud, P. O. Toxic effects of brominated flame retardants in man and in wildlife. Environment International 2003, 29 (6), 841-853.

57. Birnbaum, L. S.; Staskal, D. F. Brominated flame retardants: Cause for concern? Environmental Health Perspectives 2004, 112 (1), 9-17.

58. Ronisz, D.; Finne, E. F.; Karlsson, H.; Forlin, L. Effects of the brominated flame retardants hexabromocyclododecane (HBCDD), and tetrabromobisphenol A (TBBPA), on hepatic enzymes and other biomarkers in juvenile rainbow trout and feral eelpout. Aquatic Toxicology 2004, 69 (3), 229-245.

59. Mariussen, E.; Fonnum, F. The effect of brominated flame retardants on neurotransmitter uptake into rat brain synaptosomes and vesicles. Neurochemistry International 2003, 43 (4-5), 533-542. 